\title{
CONTRATO PRELIMINAR EMPRESARIAL
}

\author{
BLSINESS PRELIMINARY CONTRACT
}

Tarcisio Teixeiru

\begin{abstract}
Resumo:
Com o advento do Código Civil, de 2002, o contrato preliminar passou a ter uma disciplina jurídica básica, sendo seu objeto jurídico a conclusão de outro contrato, o contrato definitivo, o que o faz se distinguir deste, estando a grande utilidade do contrato preliminar no campo do Direito Empresarial. Os contratantes que optarem pelo contrato preliminar deverão necessariamente observar os requisitos essenciais (capacidade das partes e objeto licito, excluída a forma) do negócio jurídico que se pretende no futuro, e no caso de inadimplemento estará a parte sujeita à execução específica ou, na impossibilidade, à indenizar em perdas c danos. O contrato preliminar obriga as partes, não se confundindo com as negociações preliminares, apresentando-se como um instituto jurídico muito apropriado para o mundo dos negócios, notadamente quando comparado com outros, pois dá maior tempo para se verificar a qualidade do produto ou serviço que se visa contratar e para se elaborar melhor as condições da contratação definitiva. Assim, as partes preferindo que os efeitos de um contrato sejam produzidos no futuro, mas com plena convicção nesta realização. criam um vínculo jurídico por meio do contrato preliminar.
\end{abstract}

Palavras-chave: Unificação das leis obrigacionais. Autonomia do direito empresarial. Contrato preliminar. Contrato empresarial. Especificidades dos contratos empresariais. Formação dos contratos. Tratativas preliminares. Perdas e danos. Compromisso de compra e venda. Promessa de compra e venda.

Abstract:

Since the elaboration of the Civil Code in 2002 the preliminary contract became a basic legal instrument and its legal objective is to make sure that the demands of another contract will be met. This other contract would be the definitive contract, thus making the preliminary different form the definitive. The preliminary contract is more useful in the field of the Business Law. The contracting parties, which opt for the preliminary contract, should necessarily comply with the essential requirements (competence of the parts and legal purposes, not including the form) of the juristic act which they want to accomplish in the future, and in the case of a contract breach the specific party will be subjected to an execution or, if that is not possible, it will be obligated to compensate for the losses. The preliminary contract forces the parties to assume an obligation. which should not be confused with the preliminary negotiations. and it is also a very appropriate legal instrument for the business world, especially when compared with other legal instruments, since it allows more time to verify the quality of the product or service that one is considering contracting and also more time to elaborate the terms of a possible

Professor Titular da Faculdade de Direito da I niversidade Cruzeiro do Sul. Doutorando em Direito Comercial pela Faculdadu de Direito da Universidade de São Paulo.. tarcisioteixeira@adv.oabsp.org.br. 
definitive contract. Thus, if the parties want to make sure that a contract will be have the desired effec in the future, they will certainly want to establish a jural relation through a the preliminary contract.

Keywords: Unification of obligations. Autonomy of business law. Preliminary contract. Business contract. Differences of the business contracts. Constitution of mutual assent. Preliminary negociations. Damages. Agreement of sale. Promise of sale.

\section{Introdução}

A partir do Código Civil de, 2002, várias inovações surgiram quando comparado ao Código Civil, de 1916, notadamente no campo do Direito obrigacional. Dentre essas inovações, por exemplo. as questões da boa-fé, da probidade, etc., nos chamou muito atenção a inclusão da disciplina do contrato preliminar.

O contrato preliminar trata-se de um tipo contratual que há muito tempo já é utilizado nas relações obrigacionais, e que agora tem uma disciplina básica legal, que por sua vez está inserida na teoria geral dos contratos, no Código Civil, de 2002.

$\mathrm{O}$ foco do presente trabalho é analisar as disposições do contrato preliminar no Código Civil, de 2002, notadamente do ponto de vista do Direito Empresarial, até porque as pesquisas sobre contrato preliminar existentes são sempre a partir de um enfoque civilista. Agora com a "unificação das leis obrigacionais" consideramos pertinente a investigação do ponto de vista empresarialista, procurando ao máximo fugir do tão conhecido compromisso de compra e venda de imóvel.

No entanto, pensamos que essa análise não pode ser feita de forma pontual, pois o Direito Contratual é uma rede de institutos que se interligam, estando o contrato preliminar inserido nessa rede.

Então, mister será verificarmos, ainda que sucintamente, a questão da unificação dos diplomas obrigacionais com a vigência do Código Civil, de 2002, e sua respectiva concepção, a autonomia e importância do Direito Empresarial, a teoria geral dos contratos, as especificidades das relações empresariais, a classificação dos contratos e o conceito de contrato empresarial, além da boa-fé e a probidade na formação dos contratos, tudo com base no Código Civil, de 2002.

Tudo isso para, a partir dai, podermos situar e analisar a disciplina do contrato preliminar, verificando sua utilização notadamente nas relações empresariais.

Além disso, será bastante pertinente, como forma de melhor analisar a aplicação do contrato preliminar, compará-lo com outros institutos, como, por exemplo. 
a condição suspensiva, a venda a contento, a opção, o contrato normativo e o contrato com pessoa a declarar.

Preferimos utilizar no decorrer do trabalho a expressão "contrato preliminar" (apesar dos vários nomes dados ao instituto), por parecer ser mais adequada, atrelado ao fato de que foi essa a nomenclatura utilizada pelo Código Civil, de 2002, o que de certa forma nos chamou atenção para o presente estudo.

2. "Unificação das leis obrigacionais"

Com a vigência do Código Civil, de 2002, revogou-se a Parte Primeira do Código Comercial, de 1850, passando então a existir um único diploma legislativo quanto às obrigações civis e mercantis. $\mathrm{O}$ que tem feito com que muitos falem em unificação do Direito Obrigacional. onde obrigações civis e comerciais passaram a estar sob a mesma disciplina normativa.

Acontece que, o Direito Obrigacional Empresarial, mesmo antes do Código Civil, de 2002, já se socorria das normas do Direito Civil (às ordenações até 1916 e ao Código Civil após 1916), conforme previsão expressa do artigo 121 do Código Comercial.' O que nos leva perceber - de imediato - que a expressão "unificação do Direito Obrigacional" pode nem sempre ser a mais adequada.

Mas afinal de contas o que é obrigação? No Brasil não existe um conceito legal de obrigação.

Podemos nos socorrer do Direito português, em que "obrigação é o vínculo jurídico por virtude do qual uma pessoa fica adstrita para com outra à realização de uma prestação" conforme o disposto no art. 397. do Código Civil de Portugal.

Basicamente, a obrigação pode ser unilateral (por exemplo, os títulos de crédito) ou bilateral (por exemplo, os contratos), sendo que a modalidade bilateral é a que mais nos interessa no momento, por estarem nela inseridos os contratos. No Brasil também não há definição legal de contrato.

Na Itália o Código Civil, no art. 1.321, tem uma definição de contrato na qual podemos nos apoiar: "O contrato é acordo de duas ou mais partes para constituir, regular uu extinguir entre elas uma relação juridica patrimonial"

Então, com o advento do Código Civil, de 2002. muito tem se falado em unificação do Direito Privado ou unificação das obrigações civis e mercantis. Acontece que. não há unificação de "Direito Privado" ou "das obrigações" o que há é unificação

Art. 121. As regras e disposições do Direito Civil para os contratos em geral são aplicáveis aos contratos comerciais, cum as modificações e restrições estabelecidas neste Código. 
dos diplomas legais (civil e comercial), mas cada uma das obrigações (civil e comercial) continua guardando suas peculiaridades, como veremos adiante.

O legislador brasileiro seguiu, em grande medida, o modelo do Código Civil italiano de 1942, notadamente quanto às disposições sobre o Direito Obrigacional e o Direito de Empresa, sendo que no Código Civil italiano há inclusive disposições de Direito do Trabalho, mas nem por isso se falou na Itália em unificação de Direito Privado.

Se for para falar em unificação, podemos falar que mesmo antes do Código Civil, de 2002, o sistema de Direito Privado já era unificado, pois havia um regime único, de Direito Civil (Código Civil/Ordenações portuguesas antes de 1916) sendo que o Código Comercial apenas excepcionava determinadas situações específicas - as relações mercantis. ${ }^{2}$

\subsection{Concepção do Código Civil}

As leis são concebidas sempre a partir de um determinado valor social de sua época, principalmente quando se fala de um Código Civil.

Houve uma mudança de valores na sociedade brasileira no decorrer do século XX, pois o Código Civil, de 1916, foi elaborado em uma época onde a maioria das relações eram individuais (onde o Brasil era basicamente um país agrícola), daí a razão por dar maior importância para as relações familiares e a propriedade privada, pois era o que se tinha como mais importante à época.

Já o Código, de 2002, foi concebido tendo em vista, de certa forma, as complexas relações da sociedade (neste instante o Brasil já é um país com indústrias, comércios e serviços relativamente desenvolvidos), notadamente no campo das relações obrigacionais e empresariais.

Isso é percebivel pela própria disposição dos Livros dentro dos dois Códigos, conforme o quadro abaixo:

2 Nesse sentido é a posição de Fábio Konder ('omparato. "A cessão de controle acionário é negócio mercantil?". COMPARATO, Fábio Konder. Novos ensaios e pareceres de Direito Empresarial. Rio de Janeiro: Forense, 1981. p. 251. 


\begin{tabular}{|l|l|}
\hline CÓDIGO CIVIL DE 2002 & CÓDIGO CIVIL DE 1916 \\
\hline Parte Geral: & Parte Geral: \\
\hline Livro I - Das pessoas & $\begin{array}{l}\text { Livro I - Disposição preliminar ("Das } \\
\text { pessoas") }\end{array}$ \\
\hline Livro II - Dos bens & Livro II - Dos bens \\
\hline Livro III - Dos fatos jurídicos & Livro III - Dos fatos jurídicos \\
\hline Parte Especial: & Parte Especial: \\
\hline Livro I - Direito das Obrigações & Livro I - Direito de Família \\
\hline Livro II - Direito de Empresa & Livro II - Direito das Coisas \\
\hline Livro III - Direito das Coisas & Livro III - Direito das Obrigações \\
\hline Livro IV - Direito de Família & Livro IV - Direito das Sucessões \\
\hline Livro V - Direito das Sucessões & -- \\
\hline
\end{tabular}

Pela sistematização dada a cada um dos Códigos, notadamente nas Partes Especiais, podemos verificar que o legislador do Código de 2002 considerou que as relações obrigacionais e, em seguida, as questões da empresa, têm um peso importância maior para sua época, por isso optou por colocá-las adiante dos outros Livros da Parte Especial.

\subsection{Autonomia e importância do Direito Empresarial}

Mesmo com a unificação dos diplomas obrigacionais, o Direito Empresarial ${ }^{3}$ guarda autonomia com relação aos demais ramos do Direito, por possuir princípios próprios e também em razão dos usos e costumes mercantis.

O Direito Empresarial difere do Direito Civil por ser mais dinâmico nas suas relações e normas. O Direito Civil é estável e o Direito Empresarial é de criação e mutação. Na vida civil se contrata poucas vezes (se comparado com a vida mercantil) e se pensa muito antes de realizar, por exemplo, na compra e venda de imóvel para moradia da família. Na vida mercantil se contrata reiteradamente, por exemplo, contrato de distribuição, franquia, know how, etc.

Ainda é muito recorrente o uso da expressão Direito Comercial no meio juridico, sendo que falar de Direito Empresarial pode ser considerado o mesmo que falar de Dircito Comercial, mas talvez numa versão mais ampla, pois, a partir do Código Civil, de 2002, com a adoção da Teoria da Empresa, passou-se a abranger qualquer exercicio profissional de atividade econòmica organizada (exceto a de natureza infelectual) para a produção ou circulação dc bens ou serviços, diferenciando-se do regime anterior do Código (omercial de 1850 que adotava a Teoria dos Atos de Comércio.

Haroldo Malheiros Duclerc Verçosa ilustra a situação com dois círculos concêntricos, em que o Direito Empresarial seria o maior e o Direito Comercial o menor. VERÇOSA, Haroldo Malheiros Duclerc. Curso de Direito Comercial. São Paulo: Malheiros, 2004. v. I. 
No final do século XIX, Cesare Vivante, considerado o maior comercialista de todos os tempos, ao proferir conferência inaugural do curso jurídico na Universidade Bolonha, escandalizou o meio jurídico ao atacar a divisão do Direito Privado, condenando a autonomia do Direito Comercial. Mais tarde, ao se retratar, alertou que manter tal divisão era necessária, pois do contrário acarretaria prejuízo para o Direito Comercial, uma vez que o Direito Civil é quase que estático na disposição de suas normas tratando de alos isolados, já o Direito Comercial precisa de dinamismo nas suas normas em razão do constante desenvolvimento econômico tratando ele, o Direito Comercial, de negócios de massa. ${ }^{4}$

Parece então continuar válido o difundido conceito de Direito Comercial. qual seja:

O direito comercial constitui aquela parte do direito privado que tem, principalmente, por objeto regular a circulação dos bens entre aqueles que os produzem e aqueles que os consomem. (VIVANTE, Cesare. Elementi di Diritto (ommerciale. Milano: Ulrico Hoepli, 1936. p. 1).

Além disso, pode-se até dizer que o Direito Empresarial influencia o Direito Civil, pois arrisca mais inventando e experimentando coisas novas, que mais tarde serão ou não consolidadas no âmbito civil. Por exemplo, os títulos de crédito foram inventados pelo Direito Empresarial que dado o sucesso passaram a fazer parte da vida civil, primeiramente, com a letra de câmbio (para se evitar o risco de assaltos no percurso dos mercadores) e, posteriormente, com o cheque. O contrato de cartão de crédito também é um bom exemplo disso.

Rubens Requião lembra da posição de Sylvio Marcondes Machado, Autor do Anteprojeto de Código das Obrigações de 1965, na parte relativa às sociedades e ao exercício da atividade mercantil, que disse que as razões da retratação de Cesare Vivante continuavam válidas, mas nem por isso excluem a coordenação unitária de atos jurídicos concernentes ao fenômeno econômico, e que o Direito Comercial pode conviver com o Direito Civil em um código unificado. E que para Cáio Mário da Silva Pereira, que presidiu a redação do mesmo anteprojeto, a unificação do Direito das obrigações não significa a abolição da vida comercial, e uma unidade orgânica não conflita com a disciplina da vida mercantil. ${ }^{5}$

4 Conforme relata REQUIÃO, Rubens. Curso de Direiro Comercial. 22. ed. São Paulo: Saraiva, 1995. v. 1. p. 17-19.

5 Id. Ibid., p. 19-20. 
Por estas razões, mesmo com o advento do Código Civil de 2002 e a unificação dos diplomas obrigacionais, o Direito Empresarial continua sendo um ramo autônomo do Direito.

2.3. Teoria geral dos contratos e as especificidades das relações empresariais

A importância para o Direito Empresarial das disposições do Código Civil, de 2002, em matéria contratual se dá principalmente no que se refere à teoria geral dos contratos, quando trata das Disposições Gerais e da Extinção dos Contratos.

Essa parte do Código Civil, o Título V -- "Dos contratos em Geral" (421 a 480) é a disciplina, a norma básica, a legislação aplicável, o regime jurídico, a teoria geral, para todos os tipos contratuais possíveis. típicos ou atípicos, civis ou empresariais, etc.

A aplicação da disciplina dos contratos, prevista no Código Civil, às relações mercantis, deve levar em conta os princípios do Direito Empresarial, à luz do Livro II - Do Direito de Empresa, a partir do art. 966 do mesmo Código.

$\mathrm{O}$ art. 966 prevê que: "Considera-se empresário quem exerce profissionalmente atividade economicamente organizada para a produção ou a circulação de bens ou de serviços. Parágrafo único - Não se considera empresário quem exerce profissão intelectual, de natureza científica, literária ou artística, ainda com o concurso de auxiliares ou colaboradores, salvo se o exercício da profissão constituir elemento de empresa"

As relações jurídicas firmadas no âmbito do Direito Empresarial guardam especificidades que não correspondem exatamente aos negócios jurídicos firmados em sede do Direito Civil. Os negócios civis geralmente são praticados isoladamente (por exemplo, a compra ou venda de um imóvel) e em ritmo lento (com muita reflexão na maioria das vezes), já os negócios empresariais são firmados reiteradamente (por exemplo, as compras de insumos e as vendas dos produtos) e em ritmo acelerado (pois a dinâmica da atividade e o mercado assim exigem), tendo em vista que os negócios jurídicos são a essência da atividade empresarial.

O empresário (que é aquele que exerce profissionalmente atividade econômica organizada para a produção ou circulação de bens ou serviços, conforme o art. 966 do Código Civil de 2002) firma negócios jurídicos (com a mais ampla autonomia da vontade e a mais ampla liberdade de modelagem, principalmente com a utilização de condições e termos) constantemente. a fim de dinamizar sua atividade. Os negócios representam para o empresário o que o ar representa para o ser humano, quer se 
dizer que sem os negócios a vida empresarial não existe. A profissão do empresário é celebração de negócios jurídicos.

O Direito Empresarial tradicionalmente é considerado como ramo do Direito, guardando uma principiologia própria, sendo dinâmico e cambiante, ocupandose de negócios de massa, diferente dos demais ramos, notadamente do Direito Civil, que tem a peculiaridade de ser mais conservador e estável nas suas relações e quanto às mudanças, tratando de atos isolados, no sentido descrito por Cesare Vivante.

Mesmo com o advento do Código de 2002 os negócios empresariais devem ser olhados sob uma ótica diferente (com as "lentes" do Direito Empresarial) diante de suas peculiaridades e dinamismo, mesmo com o surgimento de um diploma unificado quanto às obrigações civis e empresariais. Ou seja, se antes de 2002 tínhamos duas leis obrigacionais, uma lei para contrato civil - Código Civil e outra para contrato empresarial - Código Comercial, agora só temos uma que é o Código Civil, no entanto, aplicável às duas espécies de contratos.

Podemos dizer que se cada uma das leis fosse um óculos para se enxergar as relações contratuais, teríamos o óculos do Direito Civil e o óculos do Direito Empresarial. Agora, a partir da vigência do Código Civil, de 2002, digamos que se passou a ter apenas um óculos para vermos as relações civis e empresariais, no entanto, trata-se de um óculos bifocal, onde se usa para perto e longe.

Assim sendo, com um único par de óculos (mesmo regime jurídico), uma vez identificada a relação que se trata (Direito Civil ou Empresarial) deve aplicar e interpretar a relação contratual conforme os princípios pertinentes, notadamente quanto à questão da profissionalidade do empresário, dando a devida carga valorativa.

Por exemplo, no caso de relações empresariais, na compra e venda de insumos para a linha de produção, em principio, não poderia um empresário invocar. indistintamente, o instituto da lesão previsto no Código Civil, ${ }^{6}$ dizendo que contratou sob premente necessidade ou "inexperiência", como pode ocorrer nas relações civis e de consumo, onde muitas das vezes o civil ou consumidor se vê obrigado a contratar, ou contrata por inexperiência. O empresário, na celebração de contratos, ¿̇ um profissional, não é inexperiente, nem hipossuficiente, pode sim ser incompetente.

O mesmo vale no que se refere a "resolução por onerosidade excessiva" prevista no art. 478 do Código Civil, in verbis: "Nos contratos de execução continuada ou diferida. se a prestação de uma das partes se tornar excessivamente onerosa, com extrema vantagem para a outra, em virtude de acontecimentos extraordinários e

- Art. 157 - Ocorre a lesão quando uma pessoa, sob premente nccessidade. ou por inexperiência, se obriga a prestação manifestamente desproporcional ao valor da prestação oposta. 
imprevisiveis, poderá o devedor pedir a resolução do contrato. Os efeitos da sentença que a decretar retroagirão à data da citação"

Trata-se aqui da Teoria da Imprevisão, porém certas circunstâncias são perfeitamente previsíveis pelo empresário, por exemplo, a variação de preço para aquele que compra e vende na bolsa, pois é um expert em seu negócio, contrata reiteradamente. A atividade empresarial é de risco. O empresário vive de correr riscos. Logo, o critério para se aferir à imprevisão deve ser diferente no Direito Empresarial.

Com isso, em razão do advento do Código Civil, de 2002, a valoração dada numa relação negocial empresarial deve ser diferente da dada numa relação negocial civil, pois é da essência do empresário (a luz do art. 966) a profissionalidade, com experiência presumida, na organização da atividade econômica, não podendo se perder isso de vista ao analisar os institutos nas relações negociais empresariais.

\subsection{Classificação dos contratos e o conceito de contrato empresarial}

Uma classificação é dada a partir de elementos comuns (estruturais e técnico-jurídicos), e é importante para se saber o regime jurídico e a interpretação aplicável.

Os contratos podem ser classificados de várias maneiras, por exemplo, quanto: à forma (escrita ou verbal); à solenidade (consensual. real, formal); à prestação (unilateral. bilateral-sinalagmático, plurilateral); ao ônus (oneroso ou gratuito); ao risco (comutativo ou aleatório): à previsão normativa (típico, atípico ou misto); à execução (instantânea-imediata, continuada-sucessiva, diferida); ao estabelecimento de cláusulas (paritário ou adesão); etc.

Mas para se abstrair o que venha a ser contrato ${ }^{7}$ empresarial, a classificação deve feita a partir da qualidade das partes ou Direito aplicável. Dentro dessa categoria, considerando apenas o âmbito do privado, os contratos poderiam ser classificados em: civis, de consumo e empresariais.

Contrato civil seria aquele em que, via de regra, não há a intenção de lucro com a negociação. por exemplo, quando duas pessoas naturais que são amigas (mas não necessariamente) contratam a compram e venda de um automóvel, onde a legislação aplicável é o Código Civil.

O contrato de consumo é aquele celebrado a partir da relação entre consumidor (art. $2^{\circ}$ do CDC) e fornecedor (art. $3^{\circ}$ do CDC.), onde o primeiro efetua o contrato como destinatário final do produto ou do serviço, sendo a legislação aplicável o

Levando em consideração o disposto no art. 1.321 do Código Civil italiano, quanto à definição de contrato: "O contrato $\dot{c}$ acordo de duas ou mais partes para constituir, regular ou extinguir entre elas uma relação juridica patrimonial" 
Código de Defesa do Consumidor e subsidiariamente o Código Civil, por exemplo, a compra de automóvel pelo consumidor na concessionária.

Por sua vez, o contrato empresarial é aquele celebrado pela empresa dentro de sua atividade na busca de lucro (locação mercantil, mandato mercantil, bancário, seguro), ou aquele celebrado entre empresas (interempresariais: faturização, franquia, representação comercial). São os contratos celebrados entre empresas, por exemplo, a compra e venda feita entre concessionária e montadora de veículos automotores para a revenda. O regime jurídico será o das leis especiais (subsidiariamente o Código Civil), ou, na ausência de norma específica, diretamente pela disciplina contratual do Código Civil.

Feitas estas considerações iniciais, e conceituado o contrato empresarial, poderemos a seguir tratar da disciplina do contrato preliminar no Código Civil, de 2002, sob o ponto de vista do Direito Empresarial, verificando sua utilidade.

\section{Contrato Preliminar}

\subsection{Conceito de contrato preliminar}

O contrato preliminar é aquele que tem como conteúdo a obrigação de concluir ou celebrar posteriormente outro contrato (este que será o contrato definitivo).

Vários são os conceitos dados pela doutrina ao contrato preliminar, por exemplo, para Leonardo Coviello é "un contratto che ha per oggetto un futuro contratto obbligatorio" 8

Francesco Messineo ao tratar do tema relata que:

Come nozione sommaria si puo dare questa: il preliminare è un contratto rivolto alla stipulazione di un altro (futuro) contratto. Si chiama definitivo il contratto, a cui il contratto preliminare serve di preparazione (funzione preparatoria del preliminare). (MESSINEO, Francesco. Dottrina Generale del Contratto. Terza edizione ampliata. Milano: Giuffrè. 1948. p. 199).

Para Frederico de Castro y Bravo é "convenção pela qual as partes criam em favor de uma delas, ou de cada qual, a faculdade de exigir a imediata eficácia de contrato que projetaram" $"$

8 COVIELLO, Leonardo. Dei Contratti preliminari - nel diritto modemo italiano. Milano: Societa Editrice Libraria, 1896. p. II.

- CASTRO Y BRAVO, Frederico de. La promessu de contrato, p. 42, apud GOMES, Orlando. Contratos. Rio de Janeiro: Forense, 1973. p. 142. 
Já para Caio Mário da Silva Pereira é "aquele por via do qual ambas as partes ou uma delas se comprometem a celebrar mais tarde outro contrato que será contrato principal" 10

O contrato preliminar também é chamado de pré-contrato, antecontrato, contrato preparatório, compromisso, promessa de contrato, ${ }^{11}$ contrato-promessa. ${ }^{12} \mathrm{Na}$ Itália é chamado de contratto preliminare; na França de avant contrait; na Alemanha de vorvertrag; na Espanha de contrato preliminar: em Portugal de contrato-promessa; e no Direito Romano era chamado de pactum de contrahendo. ${ }^{13}$

Preferimos utilizar a expressão "contrato preliminar" por parecer mais adequada ao instituto, atrelado ao fato de que foi essa a nomenclatura adotada pelo Código Civil, de 2002.

\subsection{Distinção de contrato definitivo}

O contrato preliminar distingue-se do contrato definitivo uma vez que aquele tem por objeto concluir este. O contrato preliminar pode ser uma promessa ou um compromisso de vender; o contrato definitivo é o contrato de venda efetivamente (se for o caso, com a transferência da propriedade).

Silvio Rodrigues, ao escrever sobre a classificação dos contratos quanto ao objeto, faz a diferenciação do contrato preliminar e contrato definitivo, considerando o contrato preliminar como uma espécie de convenção, cujo objeto é sempre o mesmo, a realização do contrato definitivo, ${ }^{14} /{ }^{15}$ para tanto as partes se socorrem dele como forma de se ajustarem previamente, criando a obrigação e ou direito de terem futuramente a conclusão de um outro contrato.

Por sua vez, o contrato definitivo seria aquele que cria obrigações e direitos para as partes, onde, por exemplo, no contrato de compra e venda o vendedor se obriga a entregar a coisa tendo o direito de receber o preço, já o comprador se obriga a entregar o preço tendo o direito de receber a coisa.

10 PERLIRA, Caio Mário da Silva. Instituições de Direito Civil - contratos. 11. ed. Rio de Janeiro: Forense, 2004. v. 3. p. 81.

1 BULGaRELli, Waldirio. Contratos mercantis. 7. ed. São Paulo: Atlas. 1993. p. 114.

12 ROPPO, Enzo. O contrato. Tradução Ana Coimbra e M. Januário C. Gomes. Coimbra: Almedina, 1988. p. 102.

13 Silvio de Salvo Venosa lembra que o pactum de contrahendo já era conhecido do Direito Romano, e que na legislação brasileira aparcceu primeiramente no Decreto-lei n. 58/37, ao tratar do compromisso de compra e venda de terrenos para pagamento em prestações. VENOSA, Silvio de Salvo. Direito Civil: teoria geral das obrigações e teoria geral dos contratos. 3. ed. São Paulo: Allas, 2003. p. 422.

I4 RODRIGUES. Silvio. Direito Civil - Dos Contratos e das Declarações Unilaterais da Vontade. 25. ed. atual. São Paulo: Saraiva, 1997. v. 3. p. 37.

is No mesmo sentido que falam Francesco Messineo e Leonardo Coviello, já citados anteriormente. 
Nem sempre é fácil a distinção do contrato preliminar com o contrato definitivo. E, notadamente quanto ao objeto, o contrato preliminar na sua feição pode se apresentar muito parecido com o definitivo conforme sua abrangência, pois quanto mais disposições e elementos o contrato preliminar contiver no seu clausulado (que também estarão no contrato definitivo) mais parecidos eles serão.

O contrato definitivo, geralmente, é mais completo que o contrato preliminar antecedente, sendo que o contrato preliminar tem como função dar às partes contratantes mais tempo para negociarem e elaborarem o clausulado do contrato definitivo.

\subsubsection{Autonomia do contrato preliminar}

Orlando Gomes ${ }^{16}$ lembra haver duas correntes que tratam da autonomia do contrato preliminar em relação ao definitivo. A primeira, influenciada pelo direito francês, nega a independência do contrato preliminar, uma vez que tendo as partes consentido no preço e na coisa, obrigando-se a certo dia, neste dia estarão obrigados, sendo que fazer se obrigarem novamente é mera inutilidade, valendo então a promessa de venda como se venda fosse.

A segunda corrente é prevalecente no sentido de que o contrato preliminar é autônomo em relação ao contrato definitivo, tendo em vista que ambos produzem efeitos distintos (sendo o objeto do primeiro a realização do segundo, e o objeto do segundo, por exemplo, a compra e venda). ${ }^{17}$

A causa do contrato preliminar está justamente na possibilidade dada às partes para assegurar a introdução diferida do regramento contratual. determinando, desde logo, sua conformação básica, a ser definida por meio de um segundo contrato, cuja conclusão está vinculativamente prevista no primeiro. Já a causa do contrato definitivo é variável conforme a sua própria função econômico-social, por exemplo. na compra e venda é a circulação de bens. ${ }^{18}$

O contrato preliminar é autônomo com relação ao contrato definitivo, mas pode ser considerado como uma fase da contratação, porque as partes querem contratar sem que todos os seus efeitos operem de imediato.

is GOMES, Orlando. Contratos. Rio de Janeiro: Forense, 1973. p. 141-142.

17 Nesse sentido relata Orlando Gomes citando: PLANIOL. Traité élémentaire de Droit (ivil Français, t. II, p. 521; COLIN e CAPITANT. Cours élémentaire de Droit Civil, i. III; PLANIOL, RIPERT e ESMEIN. Traité pratique de Droil Civil Français, t. VI, p. 190. In Contratos, Rio de Janeiro: Forense, 1973, p. 141.

Nesse sentido. TOMASETTI JÚNIOR, Alcides. Execução do contrato preliminar. 1982. Tese (Doutorado)

- Faculdade de Direito, Universidade de São Paulo, São Paulo. p. 09-10. 
Discorremos o presente trabalho a partir do ponto de vista da segunda corrente, que considera a autonomia do contrato preliminar, sendo distinto e independente do contrato definitivo, por terem obrigações típicas inconfundiveis, o primeiro a promessa de contratar, o segundo as obrigações de transferir a propriedade e pagar o preço. ${ }^{19}$

\subsection{Fundamentação}

Ao celebrar um contrato preliminar as partes têm por objeto se obrigarem a um contrato futuro que, conforme suas conveniências, não deve ou não pode ser concluído imediatamente, mas $\operatorname{sim}$ a posteriori, mas nem por isso deixam de ter uma relação obrigacional.

O contrato preliminar tem seu fundamento na ampla liberdade de contratar, que decorre da autonomia privada, em que partir do ordenamento jurídico, Constituição Federal e mais recentemente de forma explícita no Código Civil, de 2002 , art. $421,{ }^{20}$ se abstrai a possibilidade de qualquer pessoa pactuar, desde que respeite as condições mínimas impostas pelo sistema, como a capacidade do agente, o objeto lícito e a forma. ${ }^{21}$

\subsection{Finalidade}

A finalidade do contrato preliminar é ser um contrato que tem por objeto obrigar as partes desde já a celebrar um outro contrato, que é o contrato definitivo, que por sua vez, em princípio, pode ser qualquer tipo contratual, típico ou atípico.

Ao tratar do tema Francesco Messineo escreveu: Si tratta, dunque, de un contratto con peculiare finalità; esso è detto contrato preliminare [...] olireché uno strumento per la formazione del (futuro) contrato definitivo, il preliminare è um tipo di contratto con contenuto particulare. ${ }^{22}$

No entanto, poderia se questionar a prestabilidade do contrato preliminar, pois que seria supérflua sua utilização, mas tal argumento não-prospera, quando confrontado com a prática contratual, principalmente empresarial, onde os mais variados contratos são concluídos.

19 Nesse sentido, GOMF.S, Orlando. Contratos. Rio de Janeiro: Forense, 1973. p. 259-260.

20 Art. A liberdade de contratar será exercida em razão e nos limites da função social do contrato.

2) Art. 104 do Código Civil: A validade do negócio jurídico requer:

I- agente capaz;

II - objeto licito, possivel, determinado ou determinável:

III - formá prescrita ou não defesa em lei.

2 MESSINEO, Francesco. Il Contrato in Genere. Milano: Giuffrè, 1973. Tomo primo. 
Quando se fala de contrato preliminar primeira coisa que vem à mente é a promessa de venda e compra de imóvel. No meio imobiliário, é verdade, esse tipo de contrato tem grande utilidade, a exemplo podemos falar dos incorporadores imobiliários. Quando o incorporador, desejando construir unidades imobiliárias para venda, não tem recursos para a compra de terreno, ele assina contrato preliminar de compra do terreno com o proprietário. Para conseguir recursos para o início da construção também assina contrato preliminar de venda de unidades imobiliárias. Ou ainda, o contrato preliminar no mercado de imóveis pode ser usado quando os promitentes querem fazer verificações: do lado do comprador, no que se refere à efetiva propriedade do bem do vendedor e, por exemplo, o desembaraço do imóvel quanto a ônus reais; por parte do vendedor. a capacidade de pagamento e idoneidade do comprador.

Conforme Custódio da Piedade Ubaldino Miranda, comentando o Código Civil, de 2002. há vários motivos para que o contrato definitivo seja precedido pelo contrato preliminar, sendo elas: I - falta de disponibilidade do numerário; II - falta de documentos necessários; III - falta de consentimento ou autorização de terceiros; IV inexistência atual da coisa; V - complexidade da operação econômica, como, por exemplo, a aquisição de estabelecimento comercial, que exige a verificação de dados, balanços, inventários, avaliações de estoque, etc. ${ }^{23}$

Francesco Messineo faz uma ponderação que parece se amoldar ao sistema jurídico brasileiro, onde segundo o autor o contrato preliminar só pode ser utilizado quando se estiver diante de relação patrimonial: "Il preliminare appartiene esclusivamente alla cerchia del diritto patrimoniale; non esiste, nel diritto italiano, um negozio preliminare, capace di includere, ad es., anche la promessa di matrimonio" 24

\subsubsection{No âmbito empresarial}

A finalidade e a utilização do contrato preliminar não se restringem ao setor imobiliário. Muito pelo contrário, estende-se por todas as relações contratuais.

Mas é, sem sobra de dúvida, no âmbito empresarial que está a grande variedade da utilização do contrato preliminar (pois a vida das empresas nada mais é do que a constante celebração de contratos). por exemplo, na esfera do Direito Societário, nos casos de fusão, incorporação e cisão de sociedades. na opção de compra de ações e

23 Comentários ao Código Civil, no prelo, p. 147, apud ZANETTI, Cristiano de Sousa. Responsabilidad pela ruptura das negociações no Direito Civil brasileiro. 2003. Dissertação (Mestrado) Faculdade de Direito, Universidade de São Paulo, São Paulo. p. 28.

24 MESSINEO, Francesco. /l Contrato in Genere. Milano: Giuffrè. 1973. "Tomo primo. p. 535. 
cessão de controle acionário, no trespasse de estabelecimento empresarial, entre outros casos.

Em regra, sendo as partes livres para contratarem, muitas vezes a contratação imediata e definitiva não se revela adequada. tendo em vista que não se tem plena certeza da conveniência e oportunidade da contratação, notadamente do ponto de vista financeiro-econômico. Às vezes, antes de uma contratação definitiva mister se faz uma exaustão negocial, com estudos especializados, avaliações contábeis, etc.

Muitas vezes na expectativa de contratação são realizadas, na forma de tratativas preliminares, uma série de ações (reuniões, viagens, etc.), sendo que a partir desse momento deixar de contratar pode ser uma tremenda perda (diante dos dispêndios/esforços já realizados). No entanto, celebrar uma contratação definitiva, nessa fase, ainda é um risco muito alto (pois ainda não há plena certeza na contratação), o que faz as partes poderem se socorrer do contrato preliminar.

Nas compras e vendas mercantis muitas vezes, seja por questões estratégicas, seja porque o objeto do contrato principal não está totalmente apto (acabado, livre ou desembaraçado) para ser negociado, o contrato preliminar é um meio eficaz de tornarem as partes obrigadas desde já, dando certa certeza e segurança aos empresários contratantes. De um lado, aquele que já sabe haver comprador para seu produto ou serviço; de outro, aquele que já conhece o produto ou serviço a ser adquirido e o respectivo fornecedor.

Acontece que, a grande utilização do contrato preliminar se dá justamente no fato de que falta algum elemento para constituir o contrato definitivo, pode ser pelo fato de que está se esperando a realização de algum evento possível, por exemplo, alta no preço, aquecimento do mercado, etc.; ou até por mera liberalidade das partes, por exemplo, para efetuar a devida avaliação e precificação do negócio; ou mesmo por qualquer outra questão estratégica de mercado.

No mundo dos negócios muitas vezes ocorrem situações que interessam aos empresários contratarem diante de determinada situação, não sendo oportuno perder o negócio, contudo é conveniente às partes adiar sua efetivação, logo, utilizam-se do contrato preliminar para mais tarde firmarem o contrato definitivo, por cxemplo, no caso de mútuo, onde o mutuante, não dispondo de recursos livres para o empréstimo, se compromete a emprestar tão logo haja disponibilidade financeira.

A conveniência de se contratar de forma preliminar pode se dar com a intenção de verificar a qualidade do bem, ou da prestação. objeto da contratação, onde pelo lapso tumporal pode verificar se o bem é acometido por algum vício. ineficiência. 
inadequação ou qualquer tipo de superveniência, o que resultará em não conclusão do contrato definitivo. ${ }^{25}$

Então, se optassem as partes, imediatamente, por celebrar o contrato definitivo e superveniências viessem a alcançar o bem ou a prestação, remédios jurídicos não faltariam para socorrer direitos, como, por exemplo, a responsabilidade por vícios redibitórios, etc., no entanto, mister seria uma ação judicial, com toda a sua onerosidade financeira e temporal.

Já o contrato preliminar apresenta-se de forma mais segura c menos custosa para as empresas, pois em caso de qualquer irregularidade na prestação de uma das partes, é só a outra parte, a quem o negócio assim não interessar, deixar de celebrar o contrato definitivo, o que certamente é muito melhor do que ter de buscar seus direitos no Poder Judiciário (ou até em Tribunal Arbitral). ou mesmo ter de fazer a resolução contratual.

Mas, não podemos esquecer que nas negociações realizadas entre empresas o contrato preliminar deve ser visto do ponto de vista empresarial, ou seja, que as partes, os empresários, são profíssionais na arte de contratar, à luz do art. 966, do Código Civil.

\section{Do Regime Jurídico no Código Civil}

O contrato preliminar está disciplinado no Código Civil, de 2002, na sua parte especial, Livro I - Do Direito das Obrigações, Título V - Dos Contratos em Geral, Capítulo I - Das Disposições Gerais, Seção VIII - Do contrato preliminar, nos arts. 462 a 466, sendo que no Código Civil, de 1916, não havia nenhuma disposição expressa correspondente.

Por ocasião da elaboração do anteprojeto do Código (ivil. Agostinho Neves de Arruda Alvim, membro da comissão elaboradora e revisora presidida por Miguel Reale, ficou encarregado pela parte do Direito das Obrigações, em sua justificativa menciona a regulamentação do contrato preliminar, em uma seção especifica, por ser uma lacuna que se fazia sentir. ${ }^{26}$

25 Nesse sentido, MONTORO. Thereza Maria Sarfert Franco. O contrato preliminar, o novo Código Civil e a análise econômica do Direito. Revista de Direito Mercantil. Industrial, Econômico e Financeiro, São Paulo, n. 132, out./dez. 2003. p. 152.

26 Anteprojeto de Código Civil Ministério da Justiça-2. ed. rev. 1973, p. 76. 
4.1. Requisitos

O Código Civil, no artigo 462, prevê que o contrato preliminar deve conter todos os requisitos essenciais, exceto quanto à forma, do contrato definitivo. ${ }^{27}$

Os requisitos essenciais vão variar de contrato para contrato, por exemplo. na compra e venda são eles a coisa e o preço ${ }^{28}$ Logo, quando se estiver diante da formatação de um contrato preliminar deve-se atentar qual será o contrato definitivo que se tem em vista celebrar, e a partir dai verificar quais são os requisitos essenciais.

Dito isso, é importante classificar os requisitos de um negócio jurídico, ainda que sucintamente, para melhor compreender o sentido do art. 462 ao empregar a locução "requisitos essenciais" Eis que os requisitos podem ser: essenciais (essentialia negotii), naturais (naturalia negotii) e acidentais (accidentalia negotii).

Os essenciais são os exigidos pela própria substância do ato: a manifestação da vontade através do agente capaz, objeto lícito (possível, determinado ou determinável) e a forma, que deve ser obedecida se for prescrita em lei.

Os requisitos naturais são aqueles elementos peculiares ao próprio negócio em questão, ou seja, que decorrem naturalmente dele quando, por exemplo, o vendedor tem a responsabilidade pela evicção e por vícios redibitórios.

Por sua vez, os requisitos acidentais são os que podem ou não fazer parte no negócio em questão, sendo utilizados pelas partes de forma a amoldar o negócio como melhor lhe convirem, se apresentando na forma de: condição, termo ou encargo. A ausência dos requisitos acidentais não impede a realização do negócio.

Da redação do artigo 462, do Código Civil, abstrai-se que não são necessários aos contratos preliminares o acordo de vontade sobre os elementos acidentais, mas se eles estiverem presentes não haverá nenhuma implicação negativa

27 Art. 462: O cuntrato preliminar, exceto quanto à forma, deve conter todos us requisitos essenciais ao contrato a ser celebrado.

Custódio da Piedade l baldino Miranda considera que, o Código Civil de 2002 teria andado melhor se, ao invés da menção genérica a ruquisitos, tivesse se referido a elementos e requisitos. Os primeiros relacionados à existência e os segundos à validade do negócio jurídico, sendo os elementos de existência: I - a declaração de vontade: II o conteúdo; III - a forma; e os requisitos da validade: I capacidade dos agentes; 11 licitude do conteúdo: III - obscrvância da forma prescrita em lei, caso não seja duferida a forma livre. Comentários ao Código Civil, no prelo, p. 153/154, apud ZANETT1, Cristiano de Sousa. Responsabilidade pela rupura das negociações no Direito Civil brasileiro. 2003. Dissertação (Mestrado) - Faculdade de Direito, Universidade de São Paulo, São Paulo. p. 30-31.

28 Compromisso de compra e venda - Representação por simples recibo - Caracterização de contrato preliminar se as partes acordaram quanto à coisa e ao preço - Insubsistência da alegação de tratar-se de tratativas preliminares (STJ) RT 763/171 (grifos nossos).

Compromisso de compra e venda - Simples recibo de sinal de reserva - Contrato preliminar não caracterizado Falta dos requisitos legais - Cominatória pretendendo execução específica compulsória - Inadmissibilidade - Recurso extraordinário provido Inteligência do art. 639 do CPC Aplicação das Súmulas 167 e 413 (STF) RT 598/245 (grifos nossos). 
(apenas poderá fazer com que o contrato preliminar se assemelhe ainda mais com o contrato definitivo, no entanto, parece salutar que no contrato preliminar as partes apontem, no mínimo, o prazo para conclusão do contrato definitivo).

Partindo desse pressuposto, debrucemos nossa preocupação na análise dos requisitos essenciais, a capacidade do agente e o objeto lícito, excluindo a forma que durante muito tempo foi questionada pela doutrina e jurisprudência, mas que perdeu a razão de ser em decorrência da redação do referido artigo, restando dizer que a forma do contrato preliminar não precisa ser a mesma exigida para o contrato definitivo em questão, isto é, se este exigir instrumento público o contrato preliminar poderá ser por instrumento particular. ${ }^{29}$

A capacidade do agente exigida para o contrato preliminar é a mesma para o contrato definitivo que se tem em vista, devendo, desde logo, estar presente por ocasião da celebração do contrato preliminar. Então, por exemplo, no contrato preliminar de mandato, a capacidade do agente, no caso o empresário, deve desde já estar presente, devendo estar em pleno gozo de seus direitos para poder contratar, por ser requisito essencial.

Se houve incapacidade no momento da conclusão do contrato preliminar, a mesma deve ser admitida considerando assim o contrato definitivo inválido. No entanto, se houver uma incapacidade superveniente por ocasião do contrato definitivo, sendo que a época do contrato preliminar a capacidade era plena, a capacidade deve ser aferida no momento da conclusão do contrato preliminar, por se tratar o contrato definitivo da execução do contrato preliminar, e porque a superveniência de incapacidade não constitui escusa para o devedor deixar de cumprir sua obrigação assumida quando plenamente capaz. ${ }^{30}$

Quanto ao objeto, o contrato preliminar deve guardar liceidade idêntica à exigida para o contrato definitivo. O objeto deve ser acordado na coisa e no preço, no entanto, é óbvio que no meio empresarial nem sempre, por ocasião da celebração do contrato preliminar, poderá se dispor de todas as condições da negociação definitiva, no entanto, no contrato preliminar. ainda que não seja possível estipular coisa e preço determinados. é necessário que pelo menos a coisa e preço sejam determináveis.

Notadamente quanto ao preço. no mundo dos negócios muitas vezes se pactua o contrato preliminar por não poder justamente se acertar no valor, o que será apurado a partir de diretrizes estabelecidas no contrato preliminar para quantificá-lo.

3 Na Itália deve ser respeita a mesma forma. conforme dispõe o art. 1.351 do Código ('ivil italiano: "Il contratto preliminare 's nullo se non è falto nella stessa forma che la legge prescrive per il contratto definitivo".

in Nesse sentido, Orlando Gomes. Contratos. Rio de Janeiro: Forense, 1973. p. 268. 
sendo que, ai sim se encontrará o valor a ser contratado no contrato definitivo, que é o que ocorre comumente no trespasse de estabelecimento empresarial e na cessão de controle acionário.

Contudo, uma vez presentes todos os requisitos (com exceção à forma) do contrato que se tem em vista contratar, posteriormente, o contrato preliminar será verdadeiramente tido como um contrato.

Enzo Roppo ao tratar dos requisitos do contrato preliminar diz que o objeto imediato do contrato preliminar é a conclusão do definitivo, enquanto seu objeto mediato são as mesmas prestações a serem cumpridas pelas partes sob o contrato definitivo. $^{3 !}$

\subsection{Direito de arrependimento}

$\mathrm{O}$ art. 463, caput, dita que concluido o contrato preliminar. e não havendo cláusula de arrependimento, qualquer das partes terá o direito de exigir a celebração do definitivo, dando um prazo à outra para que efetive o contrato definitivo. ${ }^{32}$

Então, o contrato preliminar é irretratável, salvo se houver cláusula de arrependimento, devendo as partes cumpri-lo através da celebração do contrato definitivo, sob pena de estar sujeito à execução específica.

Note-se que a questão do arrependimento no Direito Empresarial não pode ser vista como no Direito do Consumidor. Neste ramo, o direito de arrependimento, sucintamente, existe para proteger o consumidor hipossuficiente, que se vê algumas vezes traído pelo impulso incontrolável de comprar fora do estabelecimento comercial, sendo que mais tarde "em estado de plena consciência" percebe que não poderia, ou não necessitaria, efetuar tal compra."

No Direito Empresarial, no entanto, o direito de arrependimento em grande parte das situações não se apresenta de forma adequada aos negócios jurídicos, pois quando um empresário acorda com outrem a compra ou venda de produtos ou serviços, ele, ato contínuo, já cria uma série de compromissos com fornecedores,

3 ROPPO, Enzo. Il Contralto, Milão: Giuffri, 200I, apud MARQULS, Maria Beatriz Loureiro de Andrads. Contrato preliminar - breve análise dos arts. 462 a 466 do Código Civil. Revisıa de Direito Mercantil. Industrial, Econômico e Financeiro, São Paulo, n. 132, out./dez. 2003. p. 157.

32 Art. 463. Concluido o contrato preliminar, com observância do disposto no artigo antecedente, e desde que dele não conste cláusula de arrependimento, qualquer das partes terá o direito de exigir a celebração do definitivo, assinando prazo à outra para que o efetive.

33 Contrato - Negócio envolvendo venda de empresa - Arrependimento dos compradores - Nulidade - Erro e dolo por parte dos vendedores - Justa causa inexistente - Resoluçäo do contrato - Perda do sinal Conseqüencia prevista no contrato - Prefixação de perdas e danos - Inaplicabilidade do Código de Defesa do Consumidor - Recurso não provido - (Apelação Cível n. 12.580-4 Santo André - $9^{3}$ Câmara de Direito Privado - Relator: Ruiter Oliva - 22.10.96 - V.U.), fonte: Biblioleca TJSP (grifo nosso). 
clientes. colaboradores, etc., sendo que uma vez exercido o direito de arrependimento em um contrato empresarial todos os outros compromissos assumidos e negociados poderão desmoronar. refletindo em toda a cadeia industrial. comercial, além de funcionários, fisco. etc.

Nos negócios jurídicos empresariais a previsão da possibilidade de arrependimento nem sempre é recomendável, uma vez que o empresário busca sempre a certeza e segurança nas relações, o que de certa forma uma cláusula de arrependimento pode colocar isso por terra.

No entanto, uma cláusula de arrependimento poderia em determinados casos ter o efeito de estimular as partes a renegociarem, uma vez que o cumprimento do contrato como inicialmente pactuado ensejaria uma demasiada onerosidade para uma das partes, pois ela poderia se utilizar da retratação como forma de renegociar o contrato, a fim de poder cumpri-lo de maneira não tão onerosa. ${ }^{34}$

\subsection{Registro}

Quando ao registro, o parágrafo único do art. 463 diz que o contrato preliminar deverá ser levado ao registro competente. ${ }^{35}$

O referido dispositivo trata daqueles contratos que estão sujeitos a registro, por exemplo. a escritura de compra e venda de propriedade imobiliária.

E claro que para se efetuar um registro de contrato mister será o cumprimento das exigências do Direito Registral, o que foge do objeto do presente estudo.

O registro tem o caráter de tornar público o negócio, por exemplo, a transferência de determinado bem. É uma segurança para o comprador de que aquele bem, para todos os efeitos, saiu da esfera patrimonial do vendedor, passando a compor o seu patrimônio, não ustando mais sujeito a eventual pagamento de dívida do vendedor.

Especificamente no caso do contrato preliminar, parece que a intenção do legislador foi a de que, por exemplo. uma vez registrado o contrato preliminar este passaria a constar da matrícula do imóvel (como uma espécie de "ônus/impedimento" algo parecido com o que ocorre com a hipoteca), o que de certa forma dificultaria a ação do vendedor $\mathrm{cm}$ tentar firmar novo contrato de venda do imóvel (preliminar ou definitivo) com outra pessoa de boa-fé, pois esta de posse da certidão do imóvel não

Esse é um ponto de vista que agradaria muito os simpatizantes da "visão econômica do Direito"

Art. 463. (...) Parágrafo único. O contrato preliminar dev rra ser levado ao registro competente.

Sil io de Saluo Venosa afirma que o interessado "podera" levar o contrato preliminar a registro, se o desejar, embora a lei utilize o termo "devera". Direito Ciıil: teoria geral das obrigaçōes e teoria geral dos contratos. $3^{3}$ id.. São Paulo: Atlas. 2003. p. 423. 
firmaria negócio ao verificar que a propriedade está comprometida através de contrato preliminar.

\subsection{Efeitos}

"[No contrato preliminar] los efectos juridicos normales del contrato no se producen todos inmediatamentc; se producen tan sólo algunos, porque las partes lo quieren as?" ${ }^{36}$

Para Fnzo Roppo a principal característica do contrato preliminar é a cisão dos efeitos contratuais por ele promovida, em que para a efetiva realização de uma operação unitária produzem-se primeiramente os efeitos obrigacionais (do contrato preliminar), e somente depois os efeitos eventualmente reais (do contrato definitivo). Essa cisão atende aos interesses das partes quando. por exemplo. o comprador não dispõe de recursos necessários para o pagamento do preço do bem a ser adquirido, e o vendedor (por qualquer razão) não quer ou não pode efetuar a transferência da propriedade do bem. Dessa forma. o contrato preliminar vincula as partes dando segurança em relação ao compromissário comprador e ao compromissário vendedor."

Assim, o efeito do contrato preliminar é tornar obrigatória a celebração do contrato definitivo, tornando as partes obrigadas desde já. O efeito é o da conclusão coativa do contrato definitivo. ou o de gerar o dever indenizatório.

Com o vínculo estabelecido no contrato preliminar há a faculdade de exigir que se tome eficaz através da conclusão do contrato definitivo, sendo exercido o direito por uma das partes a outra deverá cumprir.

Se houver recusa de uma das partes no cumprimento do contrato preliminar, que é a celebração do contrato definitivo, sua vontade poderá ser suprida pelo juiz que determinará que o efeito do contrato preliminar se produza (como ocorre na promessa de venda irretratável), é a chamada execução específica, ou responderá por perdas e danos em razão da inexecução.

36 MESSINEO. Francesco. Doctrina General del contrato. Tradução Espanhola Fontanarrosa, Sentis Melendo e Volterra. Buenos Aires, 1952. cap. I. n. 1, p. 352, apud Silvio Rodrigues. Direito Civil - Dos Contrabos e das Declarações Unilaterais da Limtade. vol. 3. $25^{2}$ ed.. São Paulo: Saraiva, 1997, p. 38.

37 ROPPO. Enzo. I/ Contratto. cit. p. 157 


\subsubsection{Execução específica}

A sentença que se refere o art. 464, do Código Civil, ${ }^{38}$ não pode ser considerada a vontade da parte, ela apenas determina a execução específica do contrato preliminar tornando-o contrato definitivo, em que a parte favorecida por ela terá em mãos um título judicial com os mesmos efeitos que a declaração de vontade que a parte contrária deveria manifestar. ${ }^{39}$

O que será que o referido artigo ao mencionar que "salvo se a isto se opuser a natureza da obrigação" quer dizer? Orlando Gomes dá o caminho para trilharmos em busca da resposta escrevendo que. há alguns contratos, por exemplo, os contratos intuitu personcue, onde a execução específica não tem cabimento. ${ }^{40}$ Nestes casos a execução específica deve ser substituída por perdas e danos.

No entanto, Sílvio de Salvo Venosa lembra que a execução coativa do contrato deve ser sempre perseguida, por ser a solução que mais se aproxima do pretendido pelos contratantes preliminares. ${ }^{41}$

Logo, sempre que a prestação prometida por parte do devedor for possivel (pro exemplo, nos casos de contratos reais que exigem a tradição da coisa para seu aperfeiçoamento), tanto do ponto de vista jurídico como material, deve o juiz suprir a vontade do inadimplente e dar caráter definitivo ao contrato. É evidente, desde que respeitada a liberdade individual e a dignidade da pessoa humana, o que deverá ser diagnosticado na casuística.

Então, quando o contrato preliminar tiver por objeto a futura prestação de declaração de vontade, por ocasião da celebração do contrato definitivo, uma vez sonegada tal declaração dará ensejo à execução específica, que através de sentença judicial suprirá a vontade da parte inadimplente produzindo os efeitos do contrato não concluído. É óbvio que a parte que for buscar no Judiciário a execução especifica deverá cumprir com sua prestação.

38 Art. 464. Esgotado o prazo, poderá o juiz, a pedido do interessado. suprir a vontade da parte inadimplente, conferindo caráter definitivo ao contrato preliminar, salvo se a isto se opustr a naturcza da obrigação.

39. Sobre execução específica de contrato dispõe o:

Código de Processo Civil no art. 639: "Se aquele que se comprometeu a concluir um contrato não cumprir a obrigação, a outra parte, sendo isso possivel e não excluído pelo titulo, poderá obter uma sentença que produza o mesmo efeito do contrato a ser firmado"

Cúdigo de Defesa do Consumidor no art. 48: "As declarações de vontade constantes de escritos particulares, recibos e pré-contratos relativos às relações de consumo vinculam o fornecedor, ensejando inclusive execução especifica, nos termos do art. 84 e parágrafos".

to Contratos, Rio de Janeiro: Forense, 1973, p. 147.

¿VENOSA, Silvio Salvo. Direito Civil: teoria geral das obrigaçōes e teoria geral dos contratos. 3. ed. São Paulo: Atlas, 2003. p. 422. 
A sentença judicial somente pode suprir a vontade da parte inadimplente para conferir caráter definitivo ao contrato preliminar, não podendo suprir a vontade da parte inadimplente para preencher pontos do contrato a respeito dos quais não houve acordo, por exemplo, elementos acidentais. ${ }^{42}$

A doutrina, ao falar de execução específica, cita sempre o caso do promitente vendedor de imóvel que se nega a passar a escritura definitiva de transferência de propriedade, sendo cabível ação de adjudicação compulsória onde a sentença, suprindo a vontade da parte, terá os mesmos efeitos da escritura.

Mas, no meio empresarial não é difícil se vislumbrar outras hipóteses, por exemplo, quando uma empresa se compromete, através do contrato preliminar, a vender determinado maquinário (de sua propriedade e posse) a outra empresa e não o faz, não celebrando o contrato definitivo, sendo então passivel de execução específica. Também quando um empresário detentor do controle acionário de determinada sociedade se negar a celebrar o contrato definitivo transferindo-o para o promissário comprador, ou no caso de trespasse de estabelecimento empresarial, entre outros.

\subsubsection{Perdas e danos}

Considerando que a finalidade do contrato preliminar é impor às partes a celebração de um outro contrato, o contrato definitivo, seu conteúdo poderia ser considerado uma obrigação de fazer, esta, por sua vez, que consistiria em manifestar sua vontade, em momento oportuno, na conclusão do contrato definitivo.

Mas, a princípio, o devedor da prestação de fato não poderia ser compelido a cumprir especificamente o prometido, fazendo com que sua recusa se configure em inadimplemento, convertendo a obrigação de fazer no dever de indenizar em perdas e danos. ${ }^{43}$

5. Nesse sentido, MARQUES, Maria Beatriz Loureiro de Andrade. Contrato preliminar - breve análise dos arts. 462 a 406 do Código Civil. Revista de Direito Mercantil, Industrial, Económico e Financeiro. São Paulo, n. 132, vut./dez. 2003. p. 156.

s: Art. 465. Se o estipulante não der execução ao contrato preliminar, poderá a outra parte considerá-lo desfeito, e pedir perdas e danos. 
As perdas e danos envolvem a reparação do prejuízo efetivo (danos emergentes) e o que o prejudicado deixou de ganhar (lucros cessantes). É a responsabilidade $^{44}$ de indenizar que está previsto nos artigos 402 e $403 .^{45}$

$\mathrm{Na}$ Roma antiga, pelo inadimplemento de obrigação o devedor pagava até mesmo com o seu próprio corpo: podia inclusive tornar-se escravo do seu credor. No entanto, no decorrer da história percebeu-se que esse método era ineficaz.

A solução encontrada pelos ordenamentos passou então a ser que, pelo não cumprimento das obrigações, o devedor deveria pagar uma quantia em dinheiro. Solução que na perspectiva do Direito Comercial nem sempre se releva a mais adequada. Às vezes, por hipótese, uma das partes contratantes é exclusiva detentora de determinado insumo, sendo que, mesmo recebendo a indenização, a outra parte não conseguirá no mercado. pelo menos a curto tempo. o insumo necessário à sua atividade. No entanto, a indenização é o sucedâneo, uma substituição em dinheiro, que mais se aproxima da coisa pretendida pelo credor.

O empresário sempre, notadamente com o advento do Código Civil, de

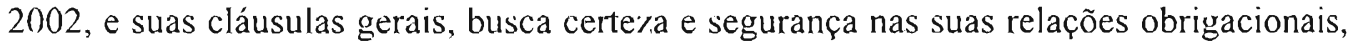
que não sendo cumpridas serão submetidas ao crivo do ordenamento jurídico, com execução especifica ou indenização.

É perceptivel que ao empresário, de modo geral, a indenização nem sempre se apresenta de forma salutar, pois isso faria com que o contrato preliminar perdesse toda a sua razão de ser. não tendo mais interesse prático, uma vez que não realizaria sua função específica que é garantir a conclusão de contrato futuro; ficando a outra parte apenas na condição de inadimplente, constituída em mora. ${ }^{46}$

44 Sobre responsabilidade é memorável o que escreveu Sylvio Marcondes Machado. apoiado em Francesco Carnclutti: "Enquanto a responsabilidade consiste num estado de sujeição a que o devedor não pode esquivar-se, pois se realiza mesmo contra a sua vontade, a obrigação pressupõe a livru manifestaçào da vontade. O devedor satisfaz espontancamente a obrigação, ao passo que suporta a responsabilidade, sem poder afastá-la. A responsabilidade exclui a liberdade, enquanto a obrigação a supōe. Limitação da Responsabilidade de Comerciante Individual. São Paulo, 1956, p. 258.

4.5 Art. 402. Salvo as exceções expressamente previstas em lei, as perdas e danos devidas ao credor abrangeın, além do que ele efetivamente perdeu, o que razoavelmente deixou de lucrar.

Art. 403. Ainda que a inexecução resulte de dolo do devedor. as perdas e danos só incluem os prejuizos efetivos e us lucros cessantes por efeito dela direito e imediato, sem prejuizo do disposto na lei processual civil.

46 Nos tempos atuais, mais do que nunca, o empresário é um profissional yue não poderia errar diante de sua expertisé. fazendo tudo de "caso pensado", além do fato de que o mercado é dinâmico e exigente. Assim, a mora (configuração da inadimplência) na vida dos negócios é muito mais desastrosa do que na vida comum (os contratos são para a empresa o que o ar é para o ser humano, por exemplo, no caso das montadoras de veículos automotores). Na vida comum, o prejuizo, "grosso modo", seria de um só; na vida dos negócios, as perdas são inúmeras, e vèm em efeito cascata muitas vezes (essa é uma das razõus pela qual surgiu o instituto da falência na intençâo de inibir a impontualidade/inadimplemento). Então, o fomecedor não poderia dar-se an luxo de ser constiluido em mora (uma vez que estará assumindo 
E justamente para evitar isso, dispõe o já citado art. 464, do Código Civil, que o juiz pode suprir a vontade da parte inadimplente dando ao contrato preliminar o caráter de contrato definitivo.

Percebe-se a força vinculante do contrato preliminar, notadamente naqueles onde não há cláusula de arrependimento, onde o juiz determinará a execução específica do contrato preliminar (conforme a natureza da obrigação), que é a celebração do contrato definitivo, ficando as perdas e danos para a última instância.

A questão das "perdas e danos" é muito importante para a estabilidade das relações socioeconômicas. Quando houver um dano prejuizo/diminuição patrimonial pelo descumprimento da obrigação, total ou parcial, ele poderá ser reparado por uma indenização.

Aqui é pertinente a consideração de que todos têm liberdade para contratar, porém, uma vez contratado, tem a responsabilidade de cumprir o avençado pacta sunt servanda - não podendo escapar da obrigação, em regra (exceção é, por exemplo, a aplicação da teoria da imprevisão, prevista no art. 478, do Código Civil), sob pena de ser condenado a pagar indenização.

\subsubsection{Danos emergentes}

É cabivel quando houver uma diminuição patrimonial ao credor, ou seja. um prejuizo de ordem econômica.

A demonstração do dano emergente cabe ao credor, isto é, o credor deverá apontar qual foi o prejuizo causado pelo descumprimento da obrigação. no caso a nãoconclusão do contrato definitivo. No caso de prestação em dinheiro será acrescida atualização monetária, conforme índices oficiais, juros, custas e honorários advocatícios.

\footnotetext{
implicitamente que não é profissional competente para cclebrar contratos empresariais). Com efeitn. sc assim acontecer, as penalidades provavelmente serão muito mais rigurusas do que as que seriam aplicadas ao civil inadimplente, notadamente as do murcado.

Aqui parece oportuno se mencionar. ainda que de forma sucinta. acerca da função econômica do contrato. uma vez que na vida negocial as relações são travadas de forma rápida, sendo o contrato o instrumento yue fornece respaldo aos atos que são praticados nas negociaçỏes, de modo que ć indispensável o pensamento de Caio Mário da Silva Pereira sobre a função econômica do contrato:

"Com o passar do tempo, entretanto, e com o desenvolvimento das atividades sociais, a função do contrato ampliou-se. Generalizou-se. Qualquer individuo sem distinçào de classe, de padrão econômico. de grau de instrução - contrata. O mundo moderno é o mundo do contrato. É a vida moderna o é também, e em tão alta escala que, se fizesse abstração por um momento do fenômeno contratual na civilização de nosso têmpo. a consequiência seria a estagnação da vida social. O homo economicus estancaria as suas atividades. $\dot{E}$ o contrato que proporciona subsistència de toda a gente. Sem ele, a vida individual regrediria, a atividade do homem limitar-se-ia aos momentos primários". PEREIRA, Caio Mario da Silva. Instituiçòes de Direito Civil Contratos. 11. ed. Rio de Janeiro: Forense. 2004. v. 3. p. 04-05.
} 
além de multa se houver previsão contratual, sendo nesse sentido o disposto no caput do artigo $404 .^{47}$

Diferentemente do artigo 1.061 do Código Civil, de 1916, o artigo 404 tem um parágrafo único, que se apresenta de forma bastante salutar, no qual prevê, caso não haja cláusula penal, uma indenização suplementar se os juros de mora não cobrirem o prejuizo. $^{48}$

\subsubsection{Lucros cessantes e atividade empresarial}

Os lucros cessantes são cabíveis ao credor no que razoavelmente deixou de lucrar pelo não cumprimento da obrigação por parte do devedor.

Uma questão sempre presente nos lucros cessantes é quanto à prova de fato futuro, ou seja, quanto ganharia se a obrigação fosse devidamente cumprida. No entanto, o legislador foi feliz. ao manter a expressão razoavelmente, ${ }^{49}$ tendo em vista que a partir daí se consegue trilhar na busca dos prováveis lucros que seriam auferidos.

Este instituto é muito relevante, notadamente no mundo dos negócios, uma vez considerada que a atividade empresarial tem por escopo o lucro, e sendo este impedido pelo inadimplemento de outrem, é questão de plena justiça a sua reposição através desse instituto.

No campo empresarial muitas vezes será necessária uma pericia especializada ${ }^{50}$ para tal apuração diante da complexidade das atividades. ${ }^{51}$

Também, mister será verificar como se deu a afetação da atividade empresarial pelo inadimplemento da obrigação, pois poderá haver uma completa ou

47 Art. 404. As perdas e danos, nas obrigações de pagamento em dinheiro. serão pagas com atualização monetária segundo indices oficiais regularmentc estabelecidos, abrangendo juros, custas è honorärios de advogado, sem prejuizo da pena convencional.

48 Art. 404. (...) Parágrafo único. Provado que os juros da mora não cobrem o prejuízo, e não havendo pena convencional, pode o juiz conceder ao credor indenização suplementar.

49 Agostinho Alvim entende que, o uso pelo legislador da locução "o que razoavelmente deixou de lucrar" significa o que o credor lucraria de acordo com o bom senso. pois hả uma presunção de que os fatos se desenrolariam dentro da normalidade, considerando os antecedentes. Da inexecução das obrigạ̧ões ‘ suas consequiêncius. 5. ed. São Paulo: Saraiva, 1980. p. 189.

Arriscamos dizer que o "razoavelmente" quer dizer que seja um meio termo, algo racional e accitavel.

Indenização - Responsabilidade civil - Lucros cessantes - Determinados a partir do periodo em que o veiculo esteve parado para reformas - Realização de pericia contábil que deve levar em conta a escrituração da própria empresa, para estimar, por comparação. o lucro auferido, no respectivo tempo por ônibus de igual caracteristica e da mesma linha - Recurso parcialmente provido. (Relator: Almeida Ribeiro - Apelação Cível n. 208.737-1 - Rio Claro - 26.05.94), fonte: Biblioteca TJSP (grifo nosso).

51 Indenização - Prestação de serviços - Publicaçào de anúncio propogandistico na lista telefônica Incorreção quanto ao bairro e zona onde se localiza a empresa-autora - Incficácia da propaganda Devolução das parcelas pagas corrigidas monetariamente - Lucros cessantes, no entanto, indevidos por não-comprovados . Sentença confirmada - JTJ 154/98, fonte: Bibliuteca TJSP (grifo nosso). 
parcial paralisação do negócio, sendo que os lucros cessantes serão indenizados na medida do lucro líquido que se apuraria. ${ }^{52}$

Só será indenizável o que efetivamente se perdeu. e o que deixou de ganhar por reflexo direto e imediato do inadimplemento da obrigação, na hipótese da não concretização do contrato definitivo, não podendo o credor-prejudicado ter "aumento de patrimônio com a indenização" Tudo isso mesmo que seja resultado de dolo do devedor. $^{53}$

\subsubsection{Dano moral}

O dano moral é algo diferente de patrimônio, pois não o afeta (pelo menos diretamente), mas sim o psíquico e/ou a reputação.

São divergentes (e muitas vezes omissas) as posições doutrinárias quanto ao cabimento do dano moral em sede de indenização por inadimplemento obrigacional. No entanto, entendemos que se pelo não-cumprimento de um contrato (aí incluída a nãoconclusão do contrato definitivo) houver prejuizos à reputação/imagem de uma sociedade empresária, seja no mercado em que opera, ou junto a fornecedores, clientes, colaboradores, etc., teria ela, em tese, o direito de pleitear dano moral ao devedor..$^{54 / 55}$

52 Nesse sentido é a tese de concurso à livre-docência, em Direito Comercial pela Faculdade de Direito do Ceará. de MATTOS. Lincoln Mourão. Das perdas e Damnos no Direito Cummercial. 1930. p. 85 e 86.

53 Art. 403. Ainda que a inexecução resulte de dolo do devedor, as perdas e danos só incluem os prejuizos efetivos e os lucros cessantes por efeito dela direto e imediato, sem prejuizo do disposto na lei processual. O artigo 403 de certa forma repete o 402, quando naquele escreve os "prejuizos efetivos" sendo que neste já estava previsto o que "efetivamente perdeu"

Ainda quanto ao artigo 403, na sua parte final utiliza-se da locução "sem prejuízo do disposto na lei processual", do que se compreende que, por exemplo, no caso de litigância de má-lë (processual) a sua condenação em nada se confunde com a de perdas e danos. Nesse sentido, Judith Martins-Costa. Comentários ao novo Código Civil - Do Inadimplemento das Obrigações coord. Sálvio de Figueiredo Teixeira. vol. V, Tomo II, Rio de Janeiro: Forense, 2003, p. 363 e 364.

54 Nesse sentido: Dano moral - Protestos indevidos de letras de câmbio, decorrentes de contrato de câmbio - Debate de mérito abstraido pela coisa julgada, referente ao acórdão, que ordenou o cancelamento dos protestos - Ilicitude a acarretar, pelo ato em si, afronta à dignidade e perda de respeitabilidade da protestada no contexto empresarial e negocial em que atua - Lesão extrapatrimonial, que não se confunde com a de caráter material e aferivel pelo abalo de crédito - Pessoa jurídica, suscetivel desse tipo de prejuízo - Fixação adequada pela sentença, mantida nesse tópico. (Apelação Civel n. 84.450-4 São Paulo - 5a Câmara de Direito Privado - Relator: Marcus Andrade - 10.12.98 - V.U.), fonte: Biblioteca TJSP (grifos nossos).

Em sentido contrário: Dano moral - Inocorência - Pessoa juridica - Abalo à credibilidade empresarial ou mercantil - Divulgação, inclusive na imprensa local, de que restaurante teria servido a seus clientes chocolates com prazo de validade vencido - Verba devida pelo fabricante dos produtos alimenticios adulterados ao estabelecimento comercial somente a titulo de lucros cessantes, uma vez que a pessoa juridica é imune a susceptibilidade dos sentimentos - Voto vencido (TJPB) RT 769/338 (grifos nossos). Súmula 227 du STJ: "A pessoa juridica pode sofrer dano moral".

ss Tratando-se a atividade negocial de risco, poderia até se pensar que nesse risco também poderia estar incluido o fato do empresário não ter alguns de seus contratos cumpridos. Ou melhor, o risco do inadimplemento contratual estaria dentro do risco da atividade negocial, o que impossibilitaria pleitear 
Agostinho Alvim considera que a indenização por dano moral pode se dar pela violação do contrato ou pela culpa aquiliana. ${ }^{50}$

\subsection{Modalidades}

\subsubsection{Unilateral}

Ocorre quando no contrato preliminar a faculdade de exigir o seu cumprimento (que é a conclusão do contrato definitivo) é de apenas uma das partes, ficando a outra parte obrigada. mas subordinada a vontade da primeira. que é a única que pode exigir o cumprimento, ou seja, obriga só uma parte a concluir o contrato definitivo. Seria quando o ofertante se obriga a manter a oferta e o ofertado tem a alternativa ou-não de aceitá-la.

Seria um direito potestativo, ${ }^{58}$ sendo que o fato de criar promessa unilateral não the tira o caráter contratual. pois é decorrente da vontade das partes. ainda que manifestada anteriormente. A promessa de doação é contrato preliminar unilateral.

\subsubsection{Bilateral}

$\mathrm{Na}$ modalidade bilateral de contrato preliminar qualquer das duas partes pode exigir da outra a execução do contrato definitivo.

Um contrato preliminar de caráter bilateral muito utilizado é o de promessa de venda e compra, que pode ter cláusula de arrependimento ou ser irretratável.

\subsection{Fases da contratação}

A contratação, de forma sucinta, poderia ser divida em três fases (assinalando que nem sempre essas fases se apresentam separadamente de forma clara):

danos morais. No entanto, isso cai por terra quando lembramos que a regra é que os contratos são firmados para serem cumpridos. sendo exceção o inadimplemento.

56 ALVIM. Agostinho. Da inexucução das obrigaçócs e suas conseqüèncias. 5. ed. São Paulo: Saraiva. 1980. p. 240.

57 Art. 466. Se a promessa de contrato for unilateral. o credor, sob pena de ficar a mesma sem efeito, deverá manifestar-se no prazo nela previsto, ou, inexistindo este, no que the for razoavelmente assinado pelo devedor.

58 Aqui é pertinente a anotação sobre condição potestativa. Ela pode ser condição simplesmente potestativa, sendo a manifestação da vuntade de uma das partes atrelada a um evento externo, ou condição puramente potestativa, onde há a manifestação da vontade de uma parte única e exclusivamente. A primeira modalidade seria lícita e aceitável e a segunda não. Vesse sentido escreveu RODRIGUES. Silvio. Direıto Civil-Parte Geral. 25. ed. São Paulo: Saraiva, 1995. v. I. 
pré-contratação (tratativas preliminares), contratação propriamente dita (celebração), e pós-contratação (execução).

Poderíamos dizer que, a formação do contrato inicia-se com as negociações preliminares, podendo passar pelo contrato preliminar (se for o caso), posteriormente à celebração do contrato definitivo, e mais adiante a execução deste.

Então, o contrato preliminar aparentemente encontra-se numa zona cinzenta, entre a fase pré-contratual e a contratação definitiva, no entanto uma forma de clarear esse fato é pela diretriz que o art. 462 dá quanto aos elementos essenciais. Possuindo o contrato preliminar todos os elementos essenciais ele pode ser tido como contrato, pois é com ele que se estabelece um vínculo obrigacional entre as partes.

Assim, o contrato preliminar é plenamente considerado como contrato. ${ }^{59}$ uma vez que as partes preordenam cláusulas do contrato principal, sujeitando certos efeitos para o contrato definitivo, havendo o consentimento e o objeto perfeitamente identificável e valorável juridicamente.

4.6.1. A boa-fé e a probidade na formação dos contratos empresariais

A boa-fé e a probidade, com previsão no art. 422, são princípios que mesmo antes da vigência do Código Civil. de 2002, já faziam parte das relações mercantis (a boa-fé era prevista no art. 131 do Código Comercial); desde as feiras medievais os comerciantes apesar de exurcer atividade especulativa deviam respeitar os demais, sob pena de serem excluídos da praça de comércio.

O art. 422 dispõe que: "Os contratantes são obrigados a guardar, assim na conclusão do contrato, como em sua execução, os princípios de probidade e boa-fé."

Para se abstrair o que seja boa-fé, podemos considerar que é o contrário de má-fé/dolo/fraude (que é a má intenção do agente). Logo, agir de boa-lé é ter "boa intenção" não ter intenção de prejudicar a outra parte. A boa-fé é o comportamento que a sociedade espera do contratante.

Probidade é a honestidade/lealdade/integridade/confiabilidade que os agentes devem ter. Um homem probo é aquele em que se pode confiar.

Assim, boa-fé e probidade se não forem expressões sinônimas tem pelo menos seus significados bem parecidos.

$\mathrm{Na}$ formação do contrato a boa-fé e a probidade também devem estar presentes, pois se trata de norma cogente, e também pelo fato de que o artigo 422 av

59 Nesse sentido, Carlo A. Nicoletti. Sul Contrato Preliminare, Milão, 1974, apud BULGARELLI. Waldirio. Contratns Mercantis. 7. ed. São Paulo: Atlas, 1993. p. 114. 
falar em "conclusão do contrato" está incluindo toda a fase pré-contratual, não só a celebração do contrato.

Isso não sendo cumprido, gera responsabilidade pré-contratual que está fundada na confiança que uma das partes tem no negócio futuro, em razão da real e justificada expectativa criada pela parte contraposta, nos investimentos feitos decorrentes dessa justificada confiança, além de outros negócios que tenha deixado de concluir.

Ilustra essa situação quando uma das partes interrompe as negociações, durante a formação do contrato, de forma desleal tomando atitudes que prejudiquem a outra parte. Imaginemos o caso de uma empresa vendedora de insumos que após um longo período de negociação convence uma empresa a comprar seu material (esta por sua vez que efetua despesas como forma de poder utilizar-se daqueles insumos, além gasto de tempo na negociação), sendo que na iminência da contratação o vendedor acaba por vender os insumos à outra empresa. A empresa prejudicada foi iludida na negociação e pode ter perdido outras possibilidades de negócios. ${ }^{60}$

É claro que isso precisa ser conciliado com o fato de que as partes são livres para negociarem e procurarem melhores negócios, além do fato de que o vínculo só nasce com o efetivo contrato. Então, estamos diante de situações talvez excepcionais, onde o marco divisor (e a possibilidade de pleitear ressarcimento de danos) seja quando houver ruptura das negociações sem justa causa, com deslealdade, por não ter observado os princípios da boa-fé e da probidade.

Assim, onde houver deslealdade por uma das partes, nas tratativas preliminares, com a ausência de boa-fé e probidade, conforme dispõe o art. 422, do Código Civil, estar-se-á diante da possibilidade de se pleitear ressarcimento de danos no campo da responsabilidade pré-contratual (por se estar na fase da formação dos contratos, não tendo sido o contrato concluido ) ${ }^{61}$

60 Nesse sentido é o disposto no art. 1337 do Código Civil italiano: "Le parti, nello svolgimento delle trattative e nella formazione del contratto, devono comportarsi secondo buona fede."

6) Nesse sentido, Enzo Roppo. O Contrato (Iradução de: Ana Coimbra e M. Januário C. Gomes). Coimbra: Almedina, 1988. p. 107, e Orlando Gomes. Contratos, Rio de Janeiro: Forense, 1973, p. 73 e 142.

Silvio de Salvo Venosa, ao tratar do tema, relata que para alguns a responsabilidade civil pré-contratual tem natureza juridica de um terceiro gênero. ao lado da responsabilidade contratual e da aquiliana, referindo-se a Caio Mário. Fala também no sentido de que pelo fato do comportamento lesivo se dar $\mathrm{cm}$ um momento precedente ao contrato. associado ao fato da necessária presença da boa-fé na contrataçào, a responsabilidade é pré-contratual. Mas posiciona-se afirmando que a questão situa-se no campo da responsabilidade extracontratual, a partir do abuso de direito (pelo fato de que alguém se dispôs a negociar c injustificadamente não o fez), falando inclusive da possibilidade de danos morais. Direito Civil: teoria geral das obrigações e teoria geral dos contratos. 3. ed. São Paulo: Atlas, 2003. p. 479-482.

Antonio de Junqueira Azevedo e Judith Martins-Costa. ao tratar da responsabilidade pela ruptura das negociações. afirmam que tal responsabilidade deve ser definida em razão da boa-fé. sendo o art. 187 do Código Civil (ato ilicito-abuso de direito) a base para definir eventual ilicitude pela ruptura das negociações. Respectivamente: "A boa-fé na formação dos contratos". Revista de Direito do Consumidor. 
A reparação dos danos sofridos e o dever de indenizar da parte contrária é decorrente da teoria da culpa in contrahendo, sendo os danos a serem ressarcidos decorrentes do interesse contratual negativo, ou seja, aqueles correspondentes às vantagens que teria obtido (se o contrato fosse concluído) somados aos danos e despesas que teria evitado (se não fossem iniciadas as negociações, e depois sem justa causa interrompidas pela outra parte). ${ }^{62}$

\subsubsection{Distinção de contrato preliminar e tratativas preliminares}

As negociações/tratativas preliminares. ou fase de puntuação podem se consubstanciar em convites para negociar. minutas, protocolos de intenção, estudos. discussões prévias, etc., que nada mais são do que meras avaliações de negócio, que antecedem à conclusão do contrato efetivamente (notadamente aqueles que envolvem interesses de maior vulto ou mais complexos, por exemplo. contrato de franquia ou de transferência de tecnologia), não criando, em regra, obrigações para as partes. $.^{63} / 64$

As negociações são meras expectativas para a realização do contrato, onde as partes discutem as condições do negócio, procurando satisfazer as exigências de ambos os lados, buscando um ponto de equilíbrio entre os interesses contrapostos, para depois concluir efetivamente o contrato. O contrato preliminar é classificado como tal, quando estiver presentes os requisitos essenciais (com exceção à forma) do contrato definitivo, o que não ocorre nas negociações.

No âmbito empresarial é comum uma empresa investir na prospecção, contatação de clientes, sem, contudo, ter êxito na conclusão do contrato. Faz parte da vida dos negócios se investir para colocar seus produtos e serviços no mercado (são os conhecidos custos de implementação), sendo que estes recursos não podem ser, em regra, objeto de indenização.

N. 3. São Paulo, 1992, p. 81/82, e A boa-fé no direıo privado. São Paulo. Revista dos Tribunais, 1999, p. 515 , respectivamente.

62 Nesse sentido, Orlando Gomes. Contratos, Rio de Janeiro: Forense, 1973, p. 67.

63 Enzo Roppo ao tratar da diferença entre contrato preliminar e tratativas preliminares diz quc: "Com o contrato-promessa, na verdade, as partes năo se obrigam simplesmente a prosseguir as negociações (permanecendo firmes os eventuais acordos já alcançados), mas obrigam-se, sem mais. a concluir um contrato comum certo conteúdo" O Contralo (tradução de: Ana Coimbra e M. Januário C. Gomes). Coimbra: Almedina. 1988. p. 102.

ot Contrato - Negociações preliminares Reunião de sócios de empresa comercial em que discutida a venda das quotas sociais de um deles - Ausência de mútuo consentimento. imprescindivel à caracterização de promessa irrevogável de compra e venda - Necessidade de o acordo de vontade abranger todos os pontos do contrato - Licito rompimento das tratativas Recurso do autor não conhecido, e parcialmente provido o dos réus. (Apclaçào Civel n. 1.474-4 - São Paulo - 2ª Câmara de Direito Privado Relator: Vasconcellos Pereira - 09.09.97 - V.U.), fonte: Biblioteca TJSP (grifos nossos). 
Basicamente, nas tratativas preliminares as partes se obrigam simplesmente a prosseguir nas negociações (permanecendo firmes os eventuais acordos já alcançados), mas não tendo força vinculatória, por sua vez no contrato preliminar, mais do que isso, as partes obrigam-se a concluir um contrato com um certo conteúdo, ou seja, o contrato definitivo. No contrato preliminar as partes já definiram os termos essenciais (ficam para depois eventualmente aspectos acessórios) da operação econômica a realizar, mas preferem deixar que seus efeitos jurídico-econômicos sejam produzidos no futuro, e ao mesmo tempo querem a certeza de que estes efeitos serão produzidos (não querendo que fiquem sujeitos à mera vontade de uma das partes), criando então desde já um vínculo jurídico. ${ }^{65}$

Waldirio Bulgarelli ao tratar do tema explica que nas negociações preliminares o vínculo obrigacional é eventual, só surgindo realmente se o contrato que se tem em vista for concluído. Então, é essa eventualidade que as distingue do contrato preliminar, pois este é um vínculo que obriga a conclusão do contrato definitivo. ${ }^{66}$

Assim, durante a fase de negociações entre empresas as promessas feitas por seus representantes para o futuro, quanto à realização da contratação. devem se transformar num compromisso, isto é, num contrato preliminar, pois senão tais promessas poderão não ser cumpridas, até porque a empresas constantemente passam por mudanças.

\subsubsection{O Caso Disco}

É de suma importância a distinção de contrato preliminar e tratativas preliminares, e isso foi demonstrado no famoso Caso Disco, onde de um lado os acionistas da Distribuidora de Comestíveis Disco S.A. e de outro o Supermercado Pão de Açúcar S.A. firmaram um "contrato preliminar para compra e venda de ações" (era esse o cabeçalho do documento/minuta), onde os primeiros se comprometiam a vender ao segundo suas ações referentes ao "Supermercado Disco"

Acontece que ficou pactuado que o preço definitivo deveria ser apurado posteriormente (no prazo de trinta dias), o que mais tarde resultou em discórdia entre as partes, levando o Supermercado Disco a propor, primeiramente, uma Ação de Consignação de Pagamento contra o Pão de Açúcar, a fim de devolver o sinal do negócio (estimado em um quarto do valor do negócio). E, em contrapartida, o Pão de Açúcar

65 ROPPO, Enzo. O Contrato. Tradução Ana Coimbra e M. Januário C. Gomes. Coimbra: Almedina, 1988. p. 102-J03.

66 Bulgarelli. Waldirio. Contratos Mercantis. 7. ed. São Paulo: Allas, 1993. p. 114. 
ajuizou, por dependência, uma Ação de Adjudicação Compulsória, pleiteando a transferência das ações alegando tratar-se de contrato preliminar.

A sentença de primeiro grau foi favorável ao Supermercado Disco julgando procedente a Ação Consignatória e improcedente a Ação Adjudicatória. O Tribunal de Justiça do Rio de Janeiro reformou a sentença. No Supremo Tribunal Federal, o processo teve como relator o ministro Moreira Alves, onde por maioria de votos prevaleceu a decisão em favor do Supermercado Disco, por considerar que mesmo tendo a minuta à denominação de "contrato preliminar" este assim não estava configurado, por não estar presentes os requisitos essenciais e acidentais ${ }^{67}$ do contrato definitivo, configurando-se em "tratativas preliminares" 68

Para Alcides Tomasetti Jr. de acordo com tal decisão vigoraria (no Direito da época Código Civil, de 1916) o princípio da identidade entre contrato preliminar e contrato definitivo, o que acabou por esvaziar a finalidade prática da contratação preliminar, que consiste precisamente em diferir a definição integral do conteúdo da avenca para momento posterior. ${ }^{69}$

\subsection{Extinção do contrato preliminar}

Se considerássemos que o contrato preliminar faz parte de uma relação complexa que termina com o contrato definitivo, a celebração dele seria apenas a produção de um dos seus efeitos.

Deixando de lado os que não consideram a autonomia do contrato preliminar em relação ao definitivo, e considerando a corrente que vem sendo seguida durante a exposição do presente trabalho, ou seja, a da autonomia do contrato preliminar, a extinção do contrato preliminar se dá pelo seu cumprimento, que é a celebração do contrato definitivo, ou pela novação.

67 Decisão que hoje afrontaria o disposto no art. 462 do Código Civil, onde expressamente diz da necessidade apenas dos requisitos essenciais, com exceção à forma.

Semelhante posição tem Custódio da Piedade Ubaldino Miranda por considerar que tal decisão não encontraria amparo no regime do Código Civil de 2002. Comentários ao Código Civil. no prelo, p. 171, apud (ristiano de Sousa Zanetti. Responsabilidade pela ruptura das negociações no Direito Civil brasileiro. Dissertação de mestrado defendida na Faculdade de Direito da Universidade de São Paulo, 2003 , p. 30.

6.8 Vide a integra do acórdão do STF RE no 88.716-RJ, $2^{\mathrm{a}}$ T.. Rel. Min. Moreira Alves, j. 11.9 .79 - m. v., com comentários de Wanderley Fernandes. In "Formação de contrato preliminar suscetivel de adjudicação compulsória" Revista de Direito Mercantil, Industrial, Econômico e Financeiro. No 80 . São Paulo: Revista dos Tribunais, outubro-dezembro/1990.

a* TOMASETTI JÚNIOR, Alcides. Execução do contrato preliminar. 1982. Tese (Doutorado) - Faculdade de Direito, Universidade de São Paulo, São Paulo. p. 244. 
A extinção do contrato preliminar poderá ser dada pela não exigência, por parte do credor, do seu cumprimento no prazo previsto, ou em prazo razoável se não houver sido previsto, conforme dispõe o art. 466 , do Código Civil ${ }^{70}$ o que é explicado pelo fato de que ninguém pode ficar eternamente vinculado por uma promessa.

A princípio, a extinção do contrato preliminar pode se dar nas formas previstas no Código Civil, Capítulo II - Da Extinção do Contrato (pertencente ao Título V - Dos Contratos em Geral, Livro I - Do Direito das Obrigações - Parte Especial), arts. 472 e seguintes, quando não forem incompatíveis com o referido instituto, a exemplo do distrato, que se opera quando for da vontade de ambas as partes.

No caso de resolução, em razão do inadimplemento de uma das partes, pode a outra pedir execução específica (extinguindo o contrato preliminar com a sentença do juiz, por exemplo, com a determinação de adjudicação compulsória de ações), ou perdas e danos.

\section{Contrato preliminar comparado com outros Institutos}

\subsection{Condição suspensiva}

Condição, conforme o disposto no art. 121. do Código Civil, é a cláusula conseqüente da vontade das partes onde o efeito do negócio juridico é subordinado a um evento futuro e incerto. ${ }^{71}$

Uma espécie de condição é a condição suspensiva. O conceito de condição suspensiva é abstraído a partir do art. 125. do Código Civil, onde ela estará presente quando as partes subordinam a eficácia do ato à condição suspensiva (evento futuro e incerto), enquanto esta não se verificar, não terá adquirido o direito que se pretende. ${ }^{72}$

$\mathrm{Na}$ condição suspensiva, enquanto a condição não ocorre, há apenas uma expectativa de direito ou possibilidade de adquirir um direito, ou seja, o negócio fica suspenso. Diferente da outra espécie de condição: a condição resolutiva, onde o negócio se aperfeiçoa de imediato, todavia sujeito a se desfazer se ocorrer à condição (evento futuro e incerto).

Então, lançamos a questão: Por que não utilizar a condição suspensiva (a princípio mais simples) em vez do contrato preliminar? Aparentemente a condição

70 Art. 466. Se a promessa de contrato for unilateral, o credor, sob pena de ficar a mesma sem efeito, deverá manifestar-se no prazo nela previsto, ou, incxistindo este, no que the for razoavelmente assinado pelo devedor.

7 Art. 121. Considera-se condição a cláusula que, derivando exclusivamente da vontade das partes, subordina o efeito do negócio jurídico a evento futuro e incerto.

72 Art. 125. Subordinando-se a eficácia do negócio jurídico a condição suspensiva, enquanto esta se não verificar, não se terá adquirido o direito, a que ele visa. 
suspensiva supriria a necessidade que se busca pelo contrato preliminar. No entanto, se analisarmos a questão do ponto de vista da forma do negócio jurídico, ao utilizar-se do contrato preliminar as partes podem contratar sem a necessidade de observar a forma do negócio jurídico definitivo, por exemplo, numa compra e venda de imóvel que se requer escritura pública, ao se socorrer do contrato preliminar pode utilizar o instrumento particular.

Já sendo a condição uma cláusula de um contrato, este estará sujeito à forma prevista em lei, ou seja, na mesma compra e venda de imóvel se as partes optarem por cláusula de condição suspensiva terão de efetuar a escritura pública (com todos os seus ônus financeiros e burocráticos). sob pena de nulidade do negócio jurídico, conforme prevê o art. 166, inc. IV do Código Civil. ${ }^{73}$

Outra questão que faz o empresário optar por utilizar-se do contrato preliminar à condição suspensiva é fato de que, o negócio jurídico que se tem em vista não depende de um fato futuro e incerto exclusivamente. Mas sim pelo fato de que a efetivação do negócio não é imediata por faltar algum elemento da contratação definitiva, ou por mera liberalidade das partes ou por questões de estratégia de mercado (além da vantagem e da possibilidade da execução específica em caso de inadimplemento). ${ }^{74}$

\subsection{Venda a contento}

A venda é feita a contento do comprador quando realizada sob condição suspensiva, onde o adquirente manifesta seu agrado, tornando-a assim perfeita e obrigatória. ${ }^{75}$

O Código Civil, de 2002, considerou por bem fazer uma pequena diferenciação (ou subdivisão) entre venda a contento e venda sujeita a prova, sendo que a venda sujeita a prova, prevista no art. 510, é também realizada sob condição suspensiva, onde a coisa deva ter as qualidades que dadas pelo vendedor e seja apta para o fim a que se destina. ${ }^{76}$

73 Art. 166. É nulo o negócio jurídico quando:

(...)

IV - não revestir a forma prescrita em lei;

21 Orlando Gomes lembra que tanto na modalidade unilateral ou bilateral o contrato preliminar pode subordinar-se a condição ou termo. Contratos, Rio de Janeiro: Forense, 1973. p. 145.

75 Código Civil: Art. 509. A venda feita a contento do comprador entende-se realizada sob condição suspensiva, ainda que a coisa lhe tenha sido entregue; e não se reputará perfeita, enquanto o adquircnte nâo manifestar seu agrado.

76 Código Civil: Art. 510. Também a venda sujeita a prova presume-se feita sob a condição suspensiva de que a coisa tenha as qualidades asseguradas pelo vendedor e seja idônea para o fim a que se destina. 
Ambas, em muitos casos em desuso nos tempos onde se procura a padronização de mercadorias e a despersonalização das mercadorias, não se confundem com o contrato preliminar.

Apesar de guardarem alguma semelhança com o contrato preliminar, elas são cláusulas possiveis em contratos de compra e venda, não sendo contrato propriamente dito, como o contrato preliminar. Isso é perceptível pela própria disposição do Código Civil, de 2002, onde a previsão da venda a contento e sujeita à prova está no Livro I - Do Direito das Obrigações. Título VI - Das várias espécies de contratos, Capitulo I - Da Compra e Venda, seção II - Das cláusulas especiais à compra e venda, subseção II - Da venda a contento e da sujeita a prova. ${ }^{77}$

Outro ponto que diferencia o contrato preliminar da venda a contento e sujeita a prova é o fato de que, o contrato preliminar pode ter como uma das funções a possibilidade do vendedor verificar se o comprador é bom pagador, o que na venda a contento e sujeita a prova, a princípio, não seria possível.

\subsection{Opção}

O contrato pelo qual se outorga a uma das partes o poder (ou a faculdade) de concluir um outro contrato é chamado de opção.

São partes do contrato de opção o promitente, que se obriga a celebrar o contrato futuro nas condições previamente ajustadas, e o promissário, que pode com seu consentimento fazer surgir o contrato em análise. O contrato de opção tem os mesmos efeitos que a proposta irrevogável, no entanto, a opção tem origem bilateral.

É parecido com o contrato preliminar em razão da obrigação de uma das partes em concluir o contrato definitivo, sendo que no contrato de opção a aceitação do promissário é o bastante para que surja o contrato definitivo, sem que seja necessária qualquer outra atitude/declaração do promitente. Assim, não tem o promitente uma prestação a cumprir, estando definitivamente vinculado à celebração do contrato futuro, e ao promissário assiste um direito potestativo de fazer surgir outro contrato.

Conforme ensina Orlando Gomes:

A opção não é um contrato preliminar. senão um negócio jurídico bilateral, mediante o qual estipulam as partes que uma delas permanece vinculada à própria declaração de vontade, enquanto a outra se reserva a faculdade de aceitála, ou não. Caracteriza-se, em suma, por ser proposta irrevogável de contratar decorrente de mútuo consenso.

$n$ Em sentido contrário é a posição de Orlando Gomes ao qualificar a venda a contento como modalidade unilateral de contrato preliminar. Contratos. Rio de Janeiro: Forense, 1973. p. 145. 
Trata-se desenganadamente, de um contrato, que não sc confunde, por isso mesmo, com a proposta firme existentc na formação dos contratos, como parte do processo da sua conclusão. Não é, entretanto, como parece a alguns escritores, um contrato perfeito, subordinado, na sua eficácia, à condição de que seja aceıte pela parte que não contraiu a obrigação, mas, ao contrário, ficou com a faculdade ou prerrogativa. (GOMES, Orlando. Contratos. Rio de Janeiro: Forense, 1973. p. 263).

Luiz Fabiano Corrêa se posiciona da seguinte forma:

"Não se confunde, outrossim, o contrato preliminar ou précontrato com a opção. [...] Fm outras palavras, a opção confere a uma das partes o direito potestativo de emitir uma declaração de vontade e assim completar o contrato para o qual a outra parte já prestou a sua própria declaração de vontade. Ao invés disso, o que do contrato preliminar ou pré-contrato advém para cada uma das partes é uma pretensão resultante do direito subjetivo à realização do contrato definitivo ou principal" (CORRÊA. Luiz Fabiano. Contratos preliminares ou pré-contratos. Revista dos Tribunais, São Paulo, n. 735. p. 743, 1997).

No contrato de opção o objeto consiste na faculdade de uma das partes fazer, sozinha, surgir um novo contrato, enquanto que para a outra parte trata-se de um negócio jurídico irrevogável.

Arriscamos a dizer, mesmo com as posições acima. que a opção poderia até se enquadrar na modalidade unilateral de contrato preliminar prevista no art. 466 do Código Civil, salvo quanto à questão dos requisitos a serem observados (tendo em vista o contrato definitivo que se pretende). necessários na opção e não necessariamente no contrato preliminar. Neste bastam apenas os requisitos essenciais (capacidade e objeto, excluída a forma). naquela mister se faz inclusive os requisitos acidentais, sendo então um enquadramento imperfeito por aproximação.

\subsection{Contrato normativo}

Contrato normativo é aquele que tem por finalidade a disciplina pela qual as partes pretendem regulamentar os seus interesses, isto é. se estatui normas a serem observadas pelas partes em futuros contratos. ${ }^{78}$

Nesse tipo de contrato há apenas a função disciplinadora. ou seja, as partes escolhem as normas para a solução dos seus conflitos de interesses em contratos futuros.

BULGaRELLI, Waldirio. Contratos Mercantis. 7. ed. São Paulo: Atlas, 1993. p. 118. 
portanto uma função normativa. Num contrato normal o conteúdo é patrimonial, onde as partes regulam seus interesses por meio do clausulado (respeitando as normas de ordem pública), não pela eleição de normas. Parte da doutrina nega a qualidade de contrato denominando-o de acordo normativo por haver apenas uma regulamentação, e não uma regulação de interesses como ocorre em um contrato normal. ${ }^{79}$

Percebe-se que no campo empresarial o contrato normativo tem utilização, notadamente no comércio internacional. Mas o exemplo mais conhecido de contrato normativo é o da convenção coletiva de trabalho, onde uma vez homologada suas normas devem ser obedecidas pelos contratos individuais de trabalho.

Waldirio Bulgarelli chega a dizer que o contrato preliminar, por disciplinar as cláusulas do contrato principal (predisposição do conteúdo contratual), pode ser considerado uma espécie de contrato normativo, ${ }^{80}$ o que, data venia, não coaduna com nossa opinião, pois no contrato preliminar se dispõe regras de cunho contratual a serem cumpridas pelos contratantes; já no contrato normativo se dispõe sobre normas de cunho legal a serem observadas e respeitadas pelas partes.

\subsection{Contrato com pessoa a declarar}

O contrato com pessoa a declarar é uma inovação trazida pelo Código Civil de 2002, na sua parte especial, Livro I Do Direito das Obrigações, Título V Dos Contratos em Geral, Capítulo I - Das Disposições Gerais, Seção IX - Do contrato com pessoa a declarar, nos arts. 467 a 471. sendo que no Código Civil de 1916 não havia nenhuma disposição correspondente. Essa inovação em termos legislativos nos chamou a atenção, principalmente quanto à forma como o mesmo poderia ser operacionalizado, e ainda o fato de que pode manter uma relação com o contrato preliminar muito próxima.

Contrato com pessoa a declarar é aquele èm que um dos contratantes no momento da celebração do contrato faculta-se no direito de indicar uma outra pessoa que ocupará sua posição contratual, com os respectivos direitos e obrigações. ${ }^{81}$

Escreveu Francesco Messineo tratando sobre o assunto:

Esso implica che il contratto è stipulato con riserva di nominare in apresso il soggeto (che può essere una persona fisica o un soggcto colletivo), il quale acquisterà $i$ diritti e assumerà gli obblighi inerenti. (MESSINEO,

\footnotetext{
79 Nesse sentido, Francesco Messineo. Dollrina Generale del Contrallo. Terza edizione ampliala, Milano: Giuffre. 1948. p. 39.

80 BULGARELLI. Waldirio. op. cit., p. 114.

\$1 Art. 467. No momento da conclusão do contrato, pode uma das partes reservar-se a faculdade de indicar a pessoa que deve adquirir os direitos e assumir as obrigaçōes dele decorrentes.
} 
Francesco. Dottrina Generale del Contratto. Terza edizione ampliata. Milano: Giulfrè, 1948. p. 166).

No dizer de Washington de Barros Monteiro:

No contrato com pessoa a declarar, o contratante pode reservar-se o direito de fazer constar outra pessoa em seu lugar" (MONTEIRO, Washington de Barros. Curso de Direito Civil - direito das obrigações. 34. ed., 2. pt. rev. e atual. por Carlos Alberto Dabus Maluf e Regina Beatriz Tavares da Silva de acordo com o novo Código Civil. São Paulo: Saraiva, 2003).

Cíntia Regina Béo ao tratar de contrato com pessoa a declarar o coloca como uma forma excepcional de formação do contrato, fugindo a regra geral onde os contratantes procedem de forma normal à formação contratual, mas um dos contratantes reserva a si a faculdade de indicar a pessoa que, no momento da celebração, por motivos lícitos, não desejando ser identificada, deverá adquirir os direitos e obrigações decorrentes do contrato. ${ }^{82}$

A parte contratante, que tem a faculdade de indicar outra pessoa, deve fazer a indicação ao outro contratante no prazo de cinco dias, ${ }^{83}$ contados da data da celebração do contrato, salvo se outro prazo for estipulado por eles. ${ }^{\$ 4}$

A pessoa que for nomeada deve aceitar sua condição através de manifestação da vontade, que somente será eficaz se for revestida da mesma forma que as partes originárias usaram no contrato ${ }^{85}$ Quer dizer que se o contrato foi feito através de instrumento público, é por instrumento público que deve ser a aceitação da pessoa declarada, se o contrato se deu na forma escrita, é por escrito que deve ser a aceitação.

Cumprida a exigência da forma, a pessoa declarada assume todos os direitos e obrigações decorrentes do contrato com efeito ex tunc, retroagindo desde do momento da celebração do contrato pelas partes originárias. Fntão a substituição será sempre retroativa, onde o nomeado/substituto/declarado (novo contratante) se sub-rogará em todos os direitos e deveres do substituido (agora ex-contratante). ${ }^{86}$

BÉO, Cintia Regina. Contratos. São Paulo: Harbra. 2004. p. 80-\$1.

83 Na Itália o prazo é de três dias, conformc dispõe o art. 1.402 do Código Civil italiano: "La dichiarazione di nominare deve essere comunicala all altra parte nel termine di tri giorni dalla stipulazione del contrallo..."

84 Caput do art. 468: "Essa indicação deve ser comunicada à outra parte no prazo de cinco dias da conclusão do contrato, se outro não tiver sido estipulado"

s5 Parágrafo único do art. 468: "A aceitação da pessoa nomeada nã̃o será eficaz se não se revestir da mesma forma que as partes usaram para o contrato".

5. Art. 469. A pessoa, nomeada de conformidade com os artigos antecedentes, adquire os dircitos e assume as obrigaçōes decorrentes do contrato, a partir do momento em que este foi cclebrado. 
A regra geral nos contratos com pessoa a declarar é que a pessoa indicada aceite a sua condição; no entanto, isso pode não ocorrer, sendo esse fato uma exceção quanto aos efeitos normais desse tipo de contrato (que se dá quando por alguma razão surge algum empecilho na nomeação). O Código Civil, ao disciplinar o assunto, diz que nestes casos os efeitos se darão somente entre os contratantes originários, não tendo extensão à pessoa que seria nomeada. ${ }^{87}$

Contudo, se por qualquer das hipóteses mencionadas a pessoa que seria nomeada não for investida na condição de contratante, o contrato permanecerá válido entre os contratantes originários, sendo que apenas a cláusula que dispõe sobre a faculdade de nomear uma pessoa é que se tornará inválida. ${ }^{8 .}$

\subsubsection{Utilidade do contrato com pessoa a declarar e a ligação com o contrato preliminar}

O contrato com pessoa a declarar pode ser usado quando o comprador atuando de forma especulativa ou como intermediário, não tendo interesse em permanecer com o bem em caráter definitivo, querendo apenas ganhar na revenda, encontrando outro comprador para o bem. adota então a opção de nomear outra pessoa a qual será proprietária do bem. ${ }^{89}$ É o que acontece, por exemplo, nas lojas de automóveis por ocasião da compra de veículo usado, pois este não é transferido formalmente à propriedade da loja, uma vez que ela firma um contrato (ainda que verbal) com aquele que está vendendo o veículo, pactuando-se que a transferência formal da propriedade será feita diretamente ao cliente que a loja encontrará para adquirir o veículo, evitando assim burocracias administrativas bem como o recolhimento de tributos.

Sem sombra de dúvida, o empresário pode fazer uso do contrato com pessoa a declarar nas mais variadas ocasiões, na medida que nos seus negócios pode haver interesses em não aparecer num primeiro momento das contratações. Deixando de lado a questão do abuso de poder econômico, imaginemos a situação de uma empresa que deseja adquirir outra, mas por questões estratégicas de mercado, além do fato de não querer que concorrentes tomem ciência da negociação, pode a empresa se socorrer de terceiro, este que se utilizará do contrato com a pessoa a declarar, e no momento

87 Art. 470. O contrato será eficaz somente entre os contratantes originários:

I - se não houver indicação de pessoa, ou se o nomeado se recusar a aceita-la;

II - se a pessoa nomeada era insolvente, e a outra pessoa o desconhecia no momentu da indicação.

Art. 47l. Se a pessoa a nomear era incapaz ou insolvente no momento da nomcação. o contrato produzirá seus efeitos entre os contratantes originários.

${ }_{88}$ Neste cenário é cabivel a seguinte questão: o contrato com pessoa a declarar é um tipo contratual ou uma cláusula contratual?

89. Nestes casos é preciso se atentar a fim de verificar se não se está ferindo alguma legislação, por exemplo, a tributária quanto à questão da circulação de mercadorias. 
oportuno indicar seu verdadeiro interessado (resta a dúvida de saber se a outra parte contratante vai concordar em assinar tal tipo de contrato). Isso pode evitar especulação dos concorrentes e possível elevação no preço do objeto da negociação.

O contrato com pessoa a declarar é muito utilizado nos contratos preliminares, por exemplo, no difundido compromisso de compra e venda de imóvel, cujo compromissário comprador reserva-se na faculdade de indicar outra pessoa para qual a transferência da propriedade será feita, por ocasião da escritura definitiva. Talve $\angle$ o ideal fosse dizer que o contrato com pessoa a declarar fosse uma espécie de contrato preliminar, ou melhor, o contrato com pessoa a declarar só poderia ser operado no contrato preliminar.

O contrato com pessoa a declarar não deixa de ser um contrato que tem uma reserva/faculdade para uma futura complementação, a eleição de um substituto na relação contratual. Assim, como no contrato preliminar em que ainda não se tem presentes todos os elementos da contratação, ou por qualquer razão não se quer contratar em definitivo, no contrato com pessoa a declarar ainda não se tem a pessoa que fará parte do contrato no futuro, ou-não se quer revelar quem será essa pessoa.

\section{Conclusão}

O contrato preliminar, instituto jurídico pelo qual as partes se obrigam a concluir outro contrato futuramente, vem sendo utilizado há muito tempo na vida dos negócios, no entanto, a partir da vigência do Código Civil, de 2002, passa a ter uma disciplina jurídica básica.

No regramento do contrato preliminar trazido pelo Código Civil, arts. 462 a 466, estão previstos: os requisitos a serem respeitados (os essenciais: capacidade das partes e objeto lícito, exceto a forma); o direito de exigir a celebração do contrato definitivo desde que não conste cláusula de arrependimento; a necessidade de levá-lo a registro; a possibilidade de o juiz suprir a vontade da parte inadimplente dando caráter definitivo ao contrato preliminar; a possibilidade de pedir perdas e danos; e a modalidade unilateral de contrato preliminar.

O contrato preliminar é autônomo com relação ao contrato definitivo, sendo uma fase da contratação, porque as partes querem um contrato, mas não querem que todos os seus efeitos operem de imediato.

$\mathrm{O}$ interesse em utilizar o contrato preliminar existe quando as partes acham conveniente e oportuno protelar a produção dos efeitos e a assunção das obrigações definitivas, mas fechando ao mesmo tempo o negócio. 
É muito útil o contrato preliminar, e pode ser ainda mais a partir do regramento do Código Civil, notadamente no meio empresarial em que muitas vezes se quer contratar, mas não se pode, por qualquer razão, fazê-lo naquele momento. Tem a função de dar aos contratantes mais tempo para verificarem a qualidade do produto ou serviço, de negociarem e de elaborarem as cláusulas do contrato definitivo.

Apesar dos estudos sobre o tema terem vertentes do ponto de vista civil, tratando do tema quase sempre do prisma do compromisso de compra e venda de imóvel, pudemos verificar que o contrato preliminar tem sua grande área de atuação no Direito Empresarial, sem perder de vista o conceito de empresário trazido pelo art. 966, do Código Civil, de 2002, que é muito importante ser verificado diante das negociações entre empresas.

Podendo surgir das negociações preliminares, o contrato preliminar tem eficácia própria, isto é, a de conclusão coativa do contrato definitivo, ou, na impossibilidade, a de gerar o dever indenizatório.

Mas, é importante a distinção do contrato preliminar e negociações preliminares, onde aquele tem caráter vinculativo e deve possuir os requisitos (com exceção à forma) do negócio que se pretende no futuro.

$\mathrm{Na}$ fase das negociações entre empresas, as promessas para o futuro devem se transformar num compromisso, ou melhor, num contrato preliminar, pois do contrário poderão não ser cumpridas, até mesmo em razão das possíveis mudanças conjunturais que as empresas estão sujeitas.

Comparando o contrato preliminar com outros institutos (condição suspensiva, venda a contento, opção, contrato normativo e contrato com pessoa a declarar) pudemos verificar que sua utilização é muito conveniente diante das vantagens trazidas por ele, como, por exemplo, evitar o "custo do Judiciário"

Contudo, percebemos que a celebração de um contrato preliminar dá uma segurança muito maior para as partes envolvidas, pois por meio dele as partes de imediato se obrigam projetando outro contrato a ser concluído adiante, por já terem definido os termos essenciais da operação econômica a realizar (ficando para depois eventualmente aspectos acessórios). Os contratantes, assim, preferem deixar que os efeitos jurídico-econômicos sejam produzidos no futuro, e ao mesmo tempo querem a certeza de que estes efeitos serão produzidos (não desejando que fiquem sujeitos à mera vontade de uma das partes), criando então desde já um vínculo jurídico em razão do contrato preliminar.

São Paulo, abril de 2006. 


\section{Referências}

ALVES, Jones Figueiredo. Novo Código Civil comentado. Ricardo Arnaldo Malheiros Fiúza (coord.). São Paulo: Saraiva, 2002.

ALVIM, Agostinho. Da inexecução das obrigações e suas conseqüências. 5. ed. São Paulo: Saraiva, 1980.

ANDRADE, Darcy Bessone de Oliveira. Do contrato. 4. ed. São Paulo, Saraiva, 1997.

AZEVEDO, Antonio de Junqueira. A boa-fé na formação dos contratos. Revista de Direito do Consumidor, São Paulo, n. 3, 1992.

BARBOSA. Pedro de Ascensão. Do Contruto-promessu. Coimbra: Coimbra Editora, 1956.

BÉO, Cintia Regina. Contratos. São Paulo: Harbra, 2004.

BULGarelLI, Waldirio. Contratos Mercantis. 7. ed. São Paulo: Atlas, 1993.

COMPARATO, Fábio Konder. A cessão de controle acionário é negócio mercantil?. Novos Ensaios e Pareceres de Direito Empresarial. Rio de Janeiro: Forense, 1981.

CORRÊA, Luiz Fabiano. Contratos preliminares ou pré-contratos. Revista dos Tribunais, São Paulo, n. 735, 1997.

COSTA. Mário Júlio de Almeida. Responsabilidade civil pela ruptura das negociações preparatórias de um contrato. Coimbra: Coimbra Editora, 1984.

COVIELLO, Leonardo. Dei Contratti preliminari nel diritto moderno italiano. Milano: Società Editrice Libraria, 1896.

DELGADO, Abel Pereira. Do contrato-promessa. Lisboa: Petrony, 1978.

FERNANDES, Wanderley. Formação de contrato preliminar suscetivel de adjudicação compulsória. Revista de Direito Mercantil, Industrial, Econômico e Financeiro, São Paulo, n. 80. out./dez. 1990.

GABRIELLI, Giovanni. Il contratto preliminare. Milano: Giuffrè, 1970.

GOMES, Orlando. Contratos. Rio de Janeiro: Forense, 1973.

MACHADO, Sylvio Marcondes. Limitação da responsabilidade de comerciante individual. São Paulo, 1956. 
MARQL'ES, Maria Beatriz Lourciro de Andrade. Contrato preliminar - breve análise dos arts. 462 a 466 do Código Civil. Revisłu de Direito Mercantil, Industrial, Econômico e Financeiro, São Paulo, n. 132, out./dez. 2003.

MARTINEZ, Pedro Romano. O subcontrato. Almedina: Coimbra, 1989.

MARTINS-COSTA, Judith. A boa-fé no direito privado. São Paulo, Revista dos Tribunais, 1999.

Comentários ao novo Código Civil - do inadimplemento das obrigações. In: TEJXEIRA, Sálvio de Figueiredo (Coord.). Rio de Janeiro: Forense, 2003. v. V, Tomo II

MATTOS, Lincoln Mourão. Das perdas c damnos no Direito Commercial. Tese (Livre-docência) Faculdade de Direito do Ceará, 1930.

MESSINEO, Francesco. Dottrina generale del contratto. Terza edizione ampliata, Milano: Giuffrè, 1948.

Il Contrato in Genere. Milano: Giuffrè, 1973. Tomo primo

MONTEIRO, Washington de Barros. Curso de Direito Civil - Direito das obrigações. 34. ed. 2. pt., rev. e atual. por Carlos Alberto Dabus Maluf e Regina Beatriz Tavares da Silva de acordo com u novo Código Civil. São Paulo: Saraiva, 2003.

MONTURO, Thereza Maria Sarfert Franco. O contrato preliminar, o novo Código Civil e a análise econômica do Direito. Revista de Direito Mercantil, Industrial, Econômico e Financeiro, São Paulo, n. 132, out./dez. 2003.

NERY JR., Nelson; e NERY, Rosa Maria de Andrade. Novo Código Civil e legislação extravagante anotados. São Paulo: Revista dos Tribunais. 2002.

PALADINI, Alberto Giusti Mauro. Il contratto preliminare. Milano: Giuffrè, 1973.

PENTEADO, Mauro Rodrigues. Formação de contrato preliminar suscetivel de adjudicação compulsória. Revista de Direito Mercantil, Industrial, Econômico é Financuiro, São Paulo, n. 39, jul./set. 1980.

PEREIRA, Caio Mário da Silva. Instituições de Dircito Civil - Contratos. 11. ed. Rio de Janeiro: Forense, 2004. v. 3.

PRATA, Ana Maria Correia Rodrigues. O contrato-promessa e o seu regime civil. Coimbra: Almedina, 1995.

REQUIÃO, Rubens. Curso de Direito Comercial. 22. ed. São Paulo: Saraiva, 1995. v. I RODRIGUES, Silvio. Direito Civil - parte geral. 25. ed. atual. São Paulo: Saraiva, 1995. v. 1 
. Direito Civil - parte geral das obrigações. 23. ed. atual. São Paulo: Saraiva, 1995. v. 2. . Direito Civil - Dos Contratos e das Declarações Unilaterais da Vontade. 25. ed. atual. São Paulo: Saraiva, 1997. v. 3

ROPPO, Enzo. O contrato. Tradução Ana Coimbra e M. Januário C. Gomes. Coimbra: Almedina, 1988.

ROQUE, Sebastião José. Direito contratual civil-mercantil. 2. ed. rev. e ampl. São Paulo: Ícone, 2003.

TOMASETTI JR., Alcides. Execução do contrato preliminar. 1982. Tese (Doutorado) - Faculdade de Direito, Universidade de São Paulo, São Paulo.

VENOSA, Sílvio de Salvo. Direito Civil: teoria geral das obrigações e teoria geral dos contratos. 3. ed. São Paulo: Atlas, 2003.

VERÇOSA, Haroldo Malheiros Duclerc. Curso de Direito Comercial. São Paulo: Malheiros, 2004. v. 1.

VIVANTE, Cesare. Elementi di Diritto Commerciale. Milano: Ulrico Hoepli, 1936.

ZANETTI, Cristiano de Sousa. Responsabilidade pela ruptura das negociações no Direito Civil brasileiro. 2003.Dissertação (Mestrado) - Faculdade de Direito, Universidade de São Paulo, São Paulo.

Anteprojeto de Código Civil - Ministério da Justiça - 2. ed. rev., 1973.

Código Civil italiano de 1942.

Código Civil português de 1966. 